Research, part of a Special Feature on Resilience and Vulnerability of Arid and Semi-Arid Social Ecological Systems

\title{
Envisioning Adaptive Strategies to Change: Participatory Scenarios for Agropastoral Semiarid Systems in Nicaragua
}

\author{
$\underline{\text { Federica Ravera }}^{1}$, David Tarrasón $^{2}$, and Elisabeth Simelton $^{3}$
}

\begin{abstract}
Historically, the semiarid social-ecological systems of the dry Central American corridor have proven resilient to pressures. However, in the last century, these systems have experienced huge environmental and socioeconomic changes that have increased the vulnerability of local livelihoods to shocks. New approaches are needed to capture complex, uncertain, cross-scale and nonlinear relationships among drivers of change and vulnerability. Therefore, to tackle this challenge, we have applied a participatory and interdisciplinary methodological framework of vulnerability assessment to a case study in northern Nicaragua. We triangulated a range of information and data from participatory and scientific research to explore historical and current drivers of changes that affect the system's components and indicators of vulnerability, represented in a 3-dimensional space in terms of ecological resilience, the socioeconomic ability of individuals to adapt to change, and an institutional capacity to buffer and respond to crisis. A projection of climatic changes combined with a participatory scenario analysis helped, then, to heuristically analyze tendencies of vulnerability in the future and to explore what policy options might enhance the system's adaptive capacity to face new pressures. Our work primarily contributes to an empirical understanding of key factors that influence vulnerability and learning about local strategies to adapt to change in semiarid agropastoral systems in Central America. We also make a methodological contribution by testing the use of a multidimensional vulnerability framework as a way of stimulating discussion among researchers, local stakeholders, and policy makers.
\end{abstract}

Key Words: agropastoral system; conceptual model; dry tropical system; Nicaragua; participatory scenario analysis; vulnerability assessment

\section{INTRODUCTION}

Dryland regions provide livelihoods for almost half of the world's poorest people (Millenium Ecosystem Assessment 2005) and are vulnerable to global changes including climate change (Eriksen and O'Brien 2007). For example, $75 \%$ of drylands in South America, Central America, and the Caribbean are seriously degraded and threatened by desertification (Scherr 1999, United Nation Convention to Combat Desertification 2004). In particular, in Central America, the "dry corridor" that stretches between Mexico and Panama (World Food Program 2002) remains largely unstudied, despite holding $25 \%$ of the region's population (Reynolds et al. 2005). In addition to the stress of climate change, the area's livelihood systems are also threatened by war, cultural and demographic changes, and political and economic instability (Martí i Puig 2004). Specifically, in the centralnorthern semiarid region of Nicaragua, $75 \%$ of the farmers live on less than U.S. \$2 per day (Marín and Pauwels 2001) and 27\% of the population is undernourished (Food and Agriculture Organization 2004). However, there are no detailed empirical studies about how livelihoods in this region are vulnerable to a changing climate, or how multiple threats interact.

In general, there is an extensive body of literature that can be drawn upon to assess the vulnerability of livelihoods to both climatic change and other

\footnotetext{
${ }^{1}$ Institute for Environmental Science and Technology (ICTA), Universitat Autònoma de Barcelona, ${ }^{2}$ Centre for Ecological Research and Forestry Applications (CREAF), ${ }^{3}$ Centre for Climate Change Economics and Policy, Sustainability Research Institute, School of Earth and Environment, University of Leeds
} 
threats. Theoretical work draws on concepts like resilience and adaptive capacity (see Gallopin 2006, Fraser et al. 2010). More empirical studies tend to use one of two approaches. Either they use top-down quantitative biophysical modeling, and are criticized for failing to integrate methods and missing key local factors that determine vulnerability, or they use bottom-up qualitative case studies that provide a vivid contextual understanding of people's adaptation strategies in the face of multiple stresses (Fussel and Klein 2006) and their future aspirations (van Aalst et al. 2008) but lack a common and integrated analytical assessment framework to enable a structured comparison between context-specific cases and to extract broader lessons. In light of the gap between topdown and bottom-up vulnerability assessments, as well as the need to conduct detailed work on drylands livelihood systems in Central America, our work has two objectives:

1. To evaluate how the multidimensional vulnerability of livelihoods to pressures in a semiarid agropastoral system in Nicaragua has been affected over time by multiple drivers.

2. To combine knowledge systems and methods, such as participatory methods with climate models, to develop scenarios for the future and link these scenarios with locally relevant adaptive strategies.

\section{STUDY AREA}

\section{Biophysiographic Components}

The case-study area is located in the department of Estelí on a semiarid plateau in northern Nicaragua $\left(13^{\circ} 09^{\prime} \mathrm{N}-86^{\circ} 14^{\prime} \mathrm{W}\right)$. It is located in the MiraflorMoropotente Terrestrial Protected Landscape (Fig. 1), which consists of three ecological zones: fluvial valleys, mountainous cloud forests, and the intermediate semiarid plateau that was dominated by tropical savannah, oak woodlands, and dry forests in the $18^{\text {th }}$ century.

\section{Climatic Features}

The climate of this semiarid region is influenced by the North American monsoon system. Annual mean temperature is $23.5^{\circ} \mathrm{C}$ and annual total rainfall is $773 \pm 195 \mathrm{~mm}$. Rainfall occurs mainly between May and October, followed by a marked dry season. An intermediate period of scarce precipitation and high temperature ("canicula") between July and August determines the first ("primera") and the second ("postrera") crop-growing season. Rainfall is concentrated into convergence zones and is also influenced by topography, thus it shows an extreme interannual variability of up to $750 \mathrm{~mm}$. The region is also exposed to droughts and floods related to the El Niño-Southern Oscillation (ENSO) phenomenon (see Appendix 1 for details).

\section{Governance System and Socioeconomic Attributes}

In terms of the socioeconomic and political landscape, since 2003 when Miraflor-Moropotente was declared a protected area, a new comanagement agreement has been in effect between local community associations, a group of medium-sized cattle ranchers, and the Nicaraguan Ministry of Natural Resources and Environment. A minority of very large commercial cattle ranchers occupy $73 \%$ of the plateau area in the region. One-third of the population remains landless, and small-scale and medium-sized mixed farming systems occupy $25 \%$ of the land and provide food, jobs, and income for half of the rural population. Livestock is the most important component of the local economy, and is used for food, as capital, as a resource for employment, and for social status. The local diet consists of maize and beans that are produced in both the primera and postrera crop-growing seasons, and these are supplemented with meat, local dairy products, vegetables and fruits from home gardens, and wild fruits from the nearby dry forests. During the dry season, the local availability of food declines and nearly half of the local population suffers from hunger and malnutrition.

\section{FRAMEWORK AND METHODS FOR ASSESSING VULNERABILITY}

Three methodological steps were used to achieve the two objectives listed above (see Fig. 2 and Appendix 2). 
Fig. 1. Map of the Miraflor-Moropotente Terrestrial Protected Landscape and land cover in 2008. The study area is located in the semiarid zone (within the black box).

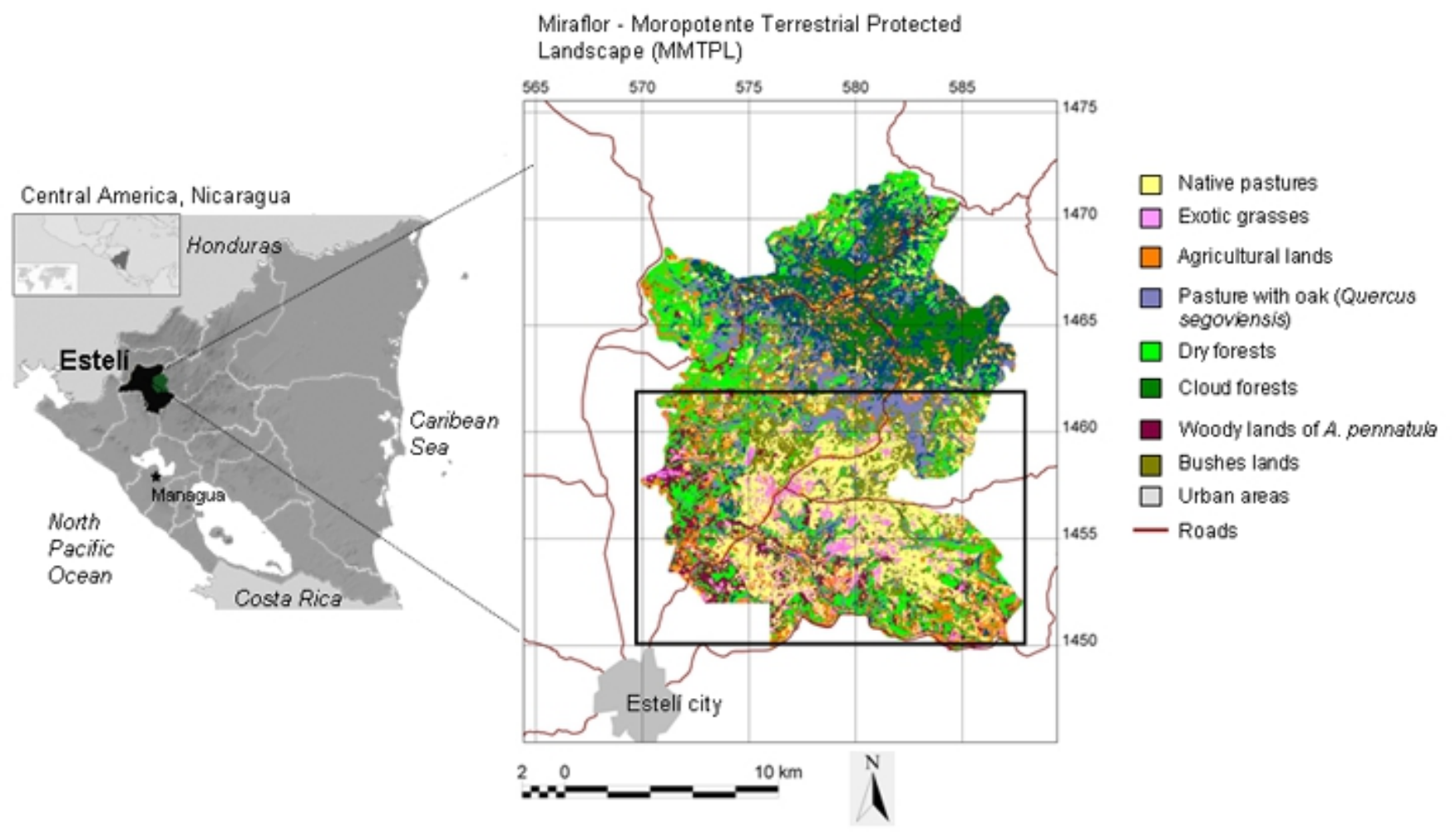

Source: satellite images ASTER and LANDSAT-7; V. Garcia-Millan and G. More, unpublished data.

\section{Step 1: Developing a Baseline Understanding of Vulnerability}

The purpose of step one was to establish a series of preliminary hypotheses about how livelihoods were changing, to identify mechanisms currently used to cope with climate and socioeconomic changes, to explore the values of ecosystem goods and services, and to discuss indicators of vulnerability. To accomplish this, we conducted a series of key informant interviews and a focus group with village elders. This information was triangulated with aerial photographs (1954, 1971, 1988, and 1996) and satellite images (2008) as well as through a literature review and review of archive material. Using the categories of relevant stakeholders identified by Ravera et al. (2009), we also conducted a perception analysis of local environmental and development issues through in-depth and semistructured interviews, selected through snowball sampling, and a first series of deliberative focus groups.

\section{Step 2: Assessing Historical and Current Vulnerability}

Interviews and survey data collected during step 1 were transcribed and analyzed using discourse analysis (Gee 1999). By following a grounded theory approach, researchers specifically looked for emergent variables and relationships that described the structure and functions of the agropastoral system (Sendzimir et al. 2007). The findings were organized into a conceptual model, accompanied by a graphical representation that helped to incorporate a diversity of knowledge and perceptions to reflect the multiscale causalities and feedbacks expressed in the transcripts. In parallel, a qualitative narrative 
Fig. 2. Methodological framework for assessing vulnerability to change.

Step 1. Developing a baseline understanding of vuinerability

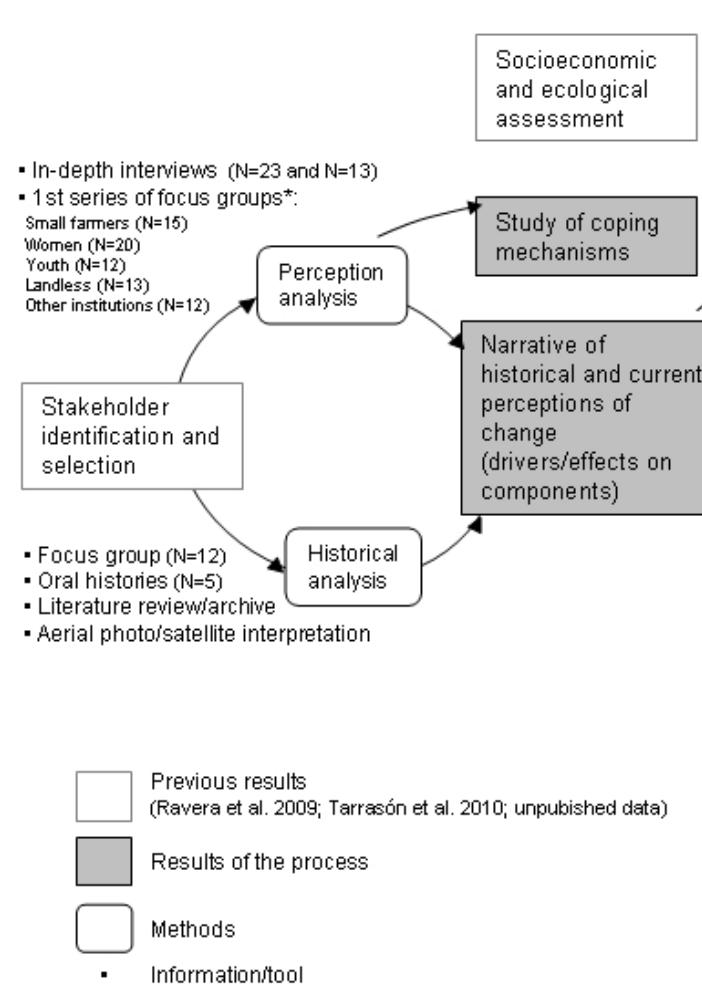

Step 2. Assessing historical and current vuinerability
- Literature review

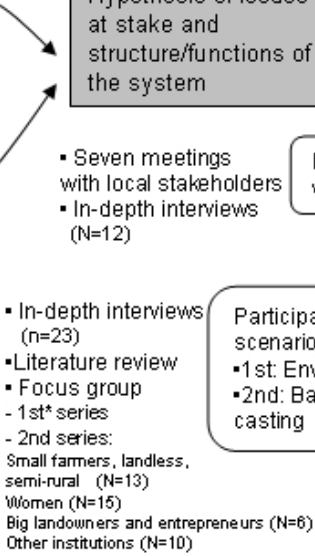

: and structure/functions of system

Step 3. Developing future vuinerability scenarios

synthesized how local agropastoral systems have become over time more or less vulnerable to perturbations. This conceptual model was then refined through a further set of in-depth interviews with key informants, extended meetings with local stakeholders, and a new series of meetings with experts. To assess changes in vulnerability, we followed Fraser (2007) who argues that multidimensional livelihood vulnerability is a function of three overlapping elements: (1) the ecological resilience of agroecosystems, referring to the extent to which the agroecosystem is able to maintain or recover key functions (Holling 1986, Holling et al. 2001) that are essential for production
(Walker and Abel 2001), (2) socioeconomic ability, referring to the extent to which the socioeconomic system helps to provide the resources or assets individuals and households require to reproduce a productive system and sustain local livelihoods in the long term and, thus, to adapt to shocks (Sens 1991, Scoones 1998) without becoming destitute (Corbett 1988), and (3) the capacity of local institutions to provide a social buffer or safety net, e.g., food-security programs or risk-alert systems, to protect livelihoods and help mitigate unexpected crises (see also Fraser et al. 2011). Field research (Ravera et al. 2009, Tarrasón et al. 2010) and literature provided the information to qualitatively 
infer current vulnerability in terms of these indicators.

\section{Step 3: Developing Future Vulnerability Scenarios}

The purpose of this step was to assess how climatic and socioeconomic drivers might affect livelihood vulnerability in the future. This phase also allowed stakeholders to deliberate policy options. Three activities were undertaken. First, an exploratory exercise was developed to capture conflicting visions about the future, by collecting images (collages and metaphors) and storylines during indepth interviews and deliberative focus groups. Second, a future climate scenario was developed based on monthly observed temperatures and precipitation levels for 1961-2007 from nearby meteorological stations with the same geographical and climatic characteristics of the study area. To develop a temperature and rainfall scenario up to 2050, we projected seasonal changes and frequency of extreme events based on literature references (Rousteenoja et al. 2003, Christensen et al. 2007). Local impacts of these changes were then identified through the literature (see Appendix 1 for details). Third, during a final series of deliberative focus groups, the conceptual model and climate scenario were used as the basis for a backcasting exercise. Each scenario (and its components) was overlapped to the conceptual model to infer future trends of changes in the performance of vulnerability indicators. Moreover, using a 3D plan of the area and a list of questions about environmental, social, and economic policies related to each envisioned future, researchers facilitated a discussion of shortand medium-term management and policy options. The alternative options were classified by researchers as either being: (1) unplanned responses undertaken spontaneously and regularly by local people as a reaction to crisis, portrayed as coping mechanisms (as defined by Osbahr et al. 2008), or (2) renewed, planned, and mainly longer timescale actions, portrayed as adaptive strategies to be implemented (as defined by Nayak 2004). Next, each scenario and policy option was ranked according to the type of uncertainty being explored, such as incomplete knowledge, unclear tendencies and the unpredictability of change, a plurality of conflicting perceptions, or ignorance. As a result, each scenario was evaluated along the three dimensions of vulnerability, forming "vulnerability trajectories" in relation to the present, or baseline.

\section{RESULTS AND ANALYSIS}

\section{Trends and Drivers in Historical and Current Vulnerability}

To analyze historical forces and patterns of changes in the study region, Nicaragua's history during the past century up to the 2006 elections is divided into four periods, summarized in Table 1 . The following narrative links historical drivers with current trends of change and is organized based on Fraser's (2007) three dimensions of vulnerability of livelihoods. Key factors and interrelationships that influence the indicators of vulnerability are summarized as a conceptual model in Fig. 3.

\section{Ecological resilience of the agropastoral system}

Three key changes stand out as affecting the resilience of the agropastoral system (see the green box in Fig. 3).

First, "native pastures lands" have experienced a slow process of ecological transition from mature grasses (Paspalum notatum Fluggë) to either a degraded state or a bush and woody (e.g., Acacia pennatula) encroached ecosystem. This change has been observed by local land users and confirmed with aerial photographs and fieldwork (Tarrasón et al. unpublished data; Fig. 4) and has been driven by both land intensification and land abandonment. Land intensification is problematic because although native grasses tolerate trampling and frequent grazing (Primavesi 2004), recurrent droughts combined with overgrazing and the introduction of exotic grass species have spread unpalatable species and inhibited the capacity of $P$. notatum to recover from climatic shocks and stresses. The historical causes of land intensification are summarized in Table 1. In contrast, some land has also been abandoned because of socioeconomic and political conditions over the last three decades. In particular, neoliberal macroeconomic policy changes and socioeconomic uncertainty (Table 1) have meant that farming is currently no longer economically viable in some areas. Oral histories and the literature (Gibson 1996, Kaimowitz 1996) suggest that land concentration combined with credit shortage have increased land abandonment. In fact, according to the interviews, low-income and highly indebted households have first intensified and then abandoned and sold lands to a few "latifundio-minifundio" and new commercial landowners. (The latifundio-minifundio land- 
Table 1. Historical drivers of change and vulnerability trends.

\begin{tabular}{|c|c|c|c|c|c|}
\hline \multirow[b]{2}{*}{ Historical period } & \multicolumn{2}{|l|}{ Multiscale drivers of change } & \multicolumn{3}{|c|}{ Local perception about historical vulnerability trends } \\
\hline & $\begin{array}{l}\text { Socioeconomic and political } \\
\text { structure }\end{array}$ & $\begin{array}{l}\text { Local land tenure, land } \\
\text { use, and natural } \\
\text { resource management }\end{array}$ & $\begin{array}{l}\text { Ecological } \\
\text { resilience }\end{array}$ & $\begin{array}{l}\text { Individual } \\
\text { socioeconomic } \\
\text { ability }\end{array}$ & $\begin{array}{l}\text { Institutional } \\
\text { capacity }\end{array}$ \\
\hline
\end{tabular}

$\begin{array}{lll}\begin{array}{l}\text { Circa 1900- } \\ \text { 1936: }\end{array} & \text { New agrarian rules } & \begin{array}{l}\text { Latifundia and } \\ \text { patronage system }\end{array} \\ \begin{array}{l}\text { Post- } \\ \text { independence } \\ \text { period }\end{array} & \begin{array}{l}\text { Export-oriented coffee } \\ \text { boom (sector of income and } \\ \text { job provider) }\end{array} & \begin{array}{l}\text { coexist with } \\ \text { communitarian system } \\ \text { and medium-sized } \\ \text { households }\end{array} \\ & \begin{array}{l}\text { Polycentric natural resource } \\ \text { management (NRM) }\end{array} & \begin{array}{l}\text { - Traditional slash and } \\ \text { burn }\end{array} \\ & & \begin{array}{l}\text { - Fire management for } \\ \text { weed and bush control }\end{array} \\ & & \text { - Mixed browsing/ } \\ & \text { grazers } \\ & & \text { - Transhumance }\end{array}$

Land concentration

("Latifundia"
1936-1979: Dictatorial regime

1950-1970: "Capitalist modernization"

- Absence of povertyalleviation programs - Coffee crisis

- Export-oriented "livestock boom" production

- Commodity food import

- Technological boom Political and economic decline started by 1970 s - Migration of landowners

- Dictatorial command-andcontrol system

1979-1990: Socialist period and the contrarevolutionary war
1980-1984: nationalization policy, price (specialized productive and food-security programs, cooperative system) agrarian reform)

- Subsidized economy, export oriented

$\mathrm{x}$ - Implementation of

"Green Revolution"

programs

Socialist command-andcontrol system

1985-1989:

Contra-revolutionary conflict and socioeconomic crisis (e.g. high inflation rate) - Intensified exportoriented agropastoral dairy production and food-oriented highenergy farming systems - Loss of transhumance system

1985-1989:

Productive military cooperatives

- Decrease in cattle population and exports - Land abandonment

$\begin{array}{ll}\text { - High landscape } & \bullet \text { Productive } \\ \text { connectedness } & \text { diversification } \\ \text { - Pastures resilient } & \text { (coffee and } \\ \text { after shock } & \text { livestock) } \\ \text { - Agro- } & \text { - Land/assets } \\ \text { biodiversity } & \text { access for } \\ \text { conservation } & \text { household } \\ \text { - Good soil quality } & \text { economy } \\ & - \text { Socio- } \\ & \text { economic } \\ & \text { exchanges } \\ & \text { between } \\ & \text { ecological zones } \\ & \text { - Commercial } \\ & \text { economy growth } \\ & - \text { Persistent coping } \\ & \text { mechanisms }\end{array}$

- Strong sense of belonging

- Strong social

capital

- Weak centralized

institutional systems

conservation access for

- Socio-

economic

exchanges

between

- Commercial

- Persistent coping

mechanisms

administered by few

families

- Introduction of

- Decreasing

native grasses

cover due to

intensification

- Initial dry forest

deforestation

- Increasing

patronage

dependence and

household

indebtedness

- Increase in

agrochemicals and high- - Progressive soil

energy and water-

intensive crops

management of

impoverishment

and substitution of

wealth-distribution

and land-access

crop varieties

inequality

- Limited

technology and

credit access for

household

economy

$\begin{array}{ll}\text { - Increasing dry } & \bullet \text { Land and NR } \\ \text { forest degradation } & \text { access for } \\ \text { and fragmentation } & \text { household } \\ \text { • Transition of } & \text { economy } \\ \text { native mature } & \text { - Diffusion of } \\ \text { grasses to bush } & \text { credit and } \\ \text { and woody cover } & \text { information access } \\ & \text { for households } \\ & \text { - Human capital } \\ & \text { reinforcement } \\ & \text { • Disrupted value- } \\ & \text { added system } \\ & \text { production } \\ & \text { - Disrupted } \\ & \text { individual and } \\ & \text { social networks } \\ & \text { during the war }\end{array}$

- Strong safety-net programs implemented - Open social conflicts on land and NRM; disrupted
- Absence of safetynet programs - High levels of conflict and confrontation over land, high levels of uncertainty networks during the war 


\begin{tabular}{|c|c|c|c|c|c|}
\hline $\begin{array}{l}\text { 1990-2006: } \\
\text { Economic } \\
\text { liberalization }\end{array}$ & $\begin{array}{l}\text { Peace accords and } \\
\text { democratic elections } \\
\text { - Neoliberal state reforms } \\
\text { (e.g., structural adjustment } \\
\text { and poverty-alleviation } \\
\text { programs) } \\
\text { - Organizational crisis } \\
\text { - Absence of investment, } \\
\text { stagnating economic } \\
\text { situation, and uncertainty } \\
\text { over International Free } \\
\text { Commercial Treaties } \\
\text { - Administrative } \\
\text { deconcentration process } \\
\text { - National Development } \\
\text { Plan prioritizes agroexports } \\
\text { and import of food } \\
\text { commodities } \\
\text { - Absence of food-security } \\
\text { programs } \\
\text { Contract manufacturing } \\
\text { diffusion in urban areas } \\
\text { International conservation } \\
\text { funds encouraged new } \\
\text { environmental priorities and } \\
\text { regulations }\end{array}$ & $\begin{array}{l}\text { Land reallocation } \\
\text { schemes (privatized } \\
\text { system) } \\
\text { - Minifundia system } \\
\text { diffusion } \\
\text { - New rules and } \\
\text { mechanisms of } \\
\text { management (e.g., } \\
\text { comanagement } \\
\text { agreement) within } \\
\text { protected areas } \\
\text { - Demographic change: } \\
\text { Population growth, } \\
\text { returns, and refugee } \\
\text { resettlement schemes; } \\
\text { youth out-migration }\end{array}$ & $\begin{array}{l}\text { - Increasing dry } \\
\text { forest patches, } \\
\text { fragmentation in } \\
\text { some private land } \\
\text { areas, and slow } \\
\text { recovery of tree } \\
\text { density and natural } \\
\text { regeneration in } \\
\text { other land areas } \\
\text { - Diffusion of } A \text {. } \\
\text { pennatula } \\
\text { - Landscape } \\
\text { fragmentation }\end{array}$ & $\begin{array}{l}\text { - Loss of the } \\
\text { financial and } \\
\text { material assets } \\
\text { (e.g., land) for } \\
\text { household } \\
\text { economy and } \\
\text { pauperization } \\
\text { process } \\
\text { - Loss in human } \\
\text { capital (access to } \\
\text { schools, health } \\
\text { systems, etc.) } \\
\text { - Progressive } \\
\text { increase in wealth } \\
\text { distribution } \\
\text { inequity } \\
\text { - Decrease in } \\
\text { investment } \\
\text { capacities of } \\
\text { commercial } \\
\text { economies }\end{array}$ & $\begin{array}{l}\text { - Weak } \\
\text { governmental social } \\
\text { programs (e.g., for } \\
\text { food security) } \\
\text { - Increasing } \\
\text { dependence on } \\
\text { external aid } \\
\text { - Latent social } \\
\text { confrontation and } \\
\text { conflict over the } \\
\text { control of protected- } \\
\text { area management }\end{array}$ \\
\hline
\end{tabular}

tenure system referred, in Latin American countries, to large estates of lands administered by few families with a patronage system [Latin: latus, "spacious" + fundus, "farm, estate"] scattered with tiny land plots [Latin: minus, "minor" + fundus, "farm, estate"]). At the same time, economic stagnation and unclear land tenure have both reduced investments in technology, land management, and labor. As a result, rural workers have passively exercised an opposition to exploitation and inequality by working less efficiently, and have indirectly contributed to pasturelands encroachment. Other factors have also affected the state of native pastures, such as changes in environmental awareness that have driven the implementation of new environmental priorities and policies. For example, all interviews revealed that since the area was declared "protected," local alliances and rules have been re-established to defend small farmers from being shut out of land access and management by large-scale landowners (Ravnborg 2008). Although the implementation of new management practices such as fire, a logging ban, and silvopastoral practices has provided in situ benefits mainly during the dry season, this has resulted in bushes and trees spreading drought-resistant species such as A. pennatula, and the consequent inhibition of native grasses (Peguero and Espelta, unpublished data). These changes have affected the resilience of the ecosystem by reducing soil protection, threatening functional diversity such as species control of native grasses (sensu Folke et al. 1996), decreasing productivity of pastures over a range of climatic perturbations (Walker et al. 1999) and favoring landscape fragmentation. Consequently, the degradation of pastureland has decreased dairy and meat production, increased the debt-to-income ratio for small farmers, reinforced household food insecurity, and reduced profits for commercial landowners.

Second, "agricultural lands" have experienced a decrease in yields and profitability, just as the impact of climatic events (e.g., harvest losses) and economic crises, e.g., price volatility, have increased. For a long time, subsistence farmers had maintained a traditional grain system that minimized external inputs to reduce costs and preserved long-term productivity. Nevertheless, traditional grain crops have progressively been replaced with a more intense mixed-farming system, e.g., cash and fodder crops (Table 1). Despite providing a short-term boost of high productivity, this intensification has accelerated a long-term process of erosion in agrobiodiversity and soil quality. In fact, intensified agriculture reduces 
Fig. 3. Overall conceptual model of the agropastoral system.
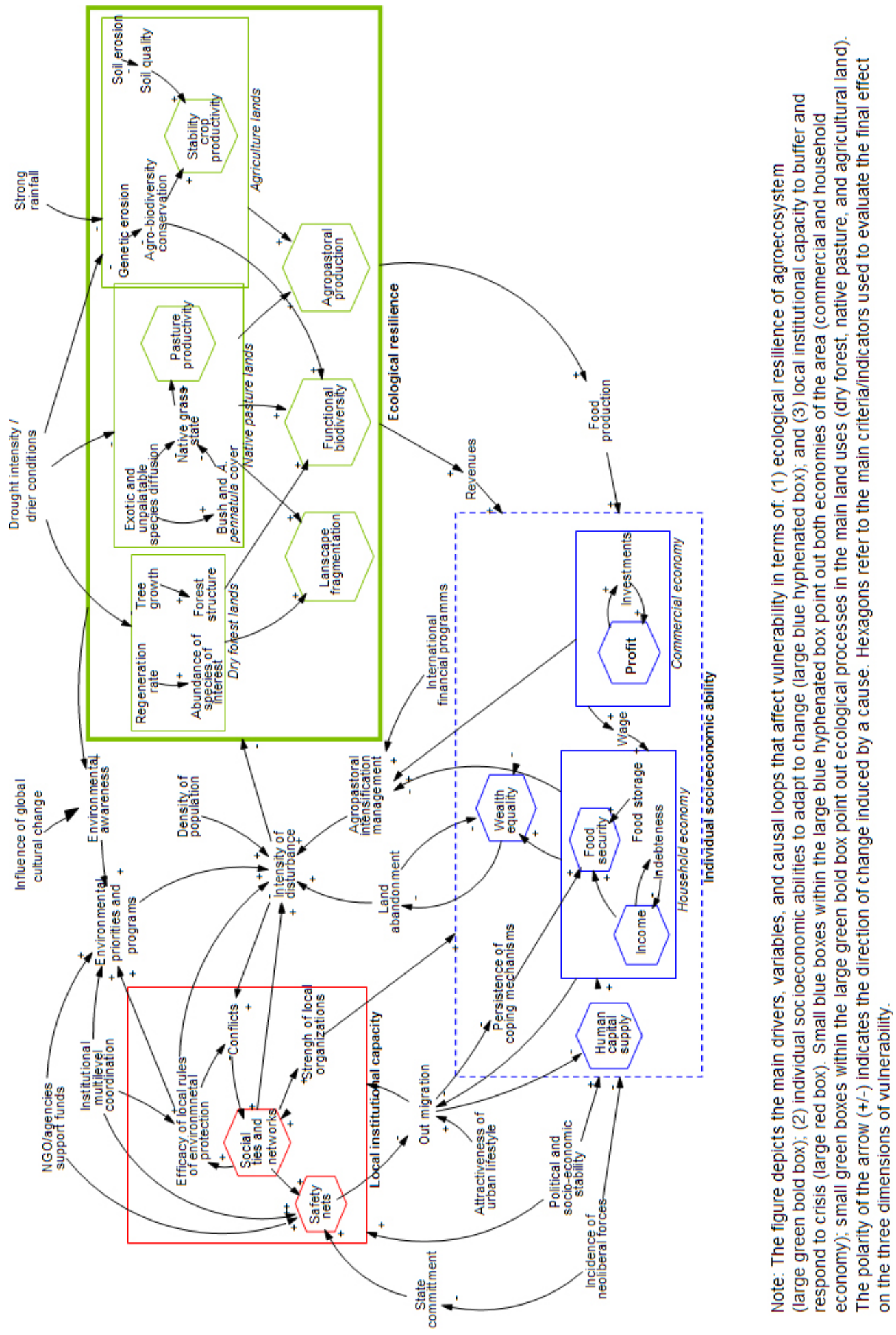
Fig. 4. Bush encroachment trends $(1954,1971,1988$, and 1996) in the study area (the area within the white line highlights the changes in shrub cover).
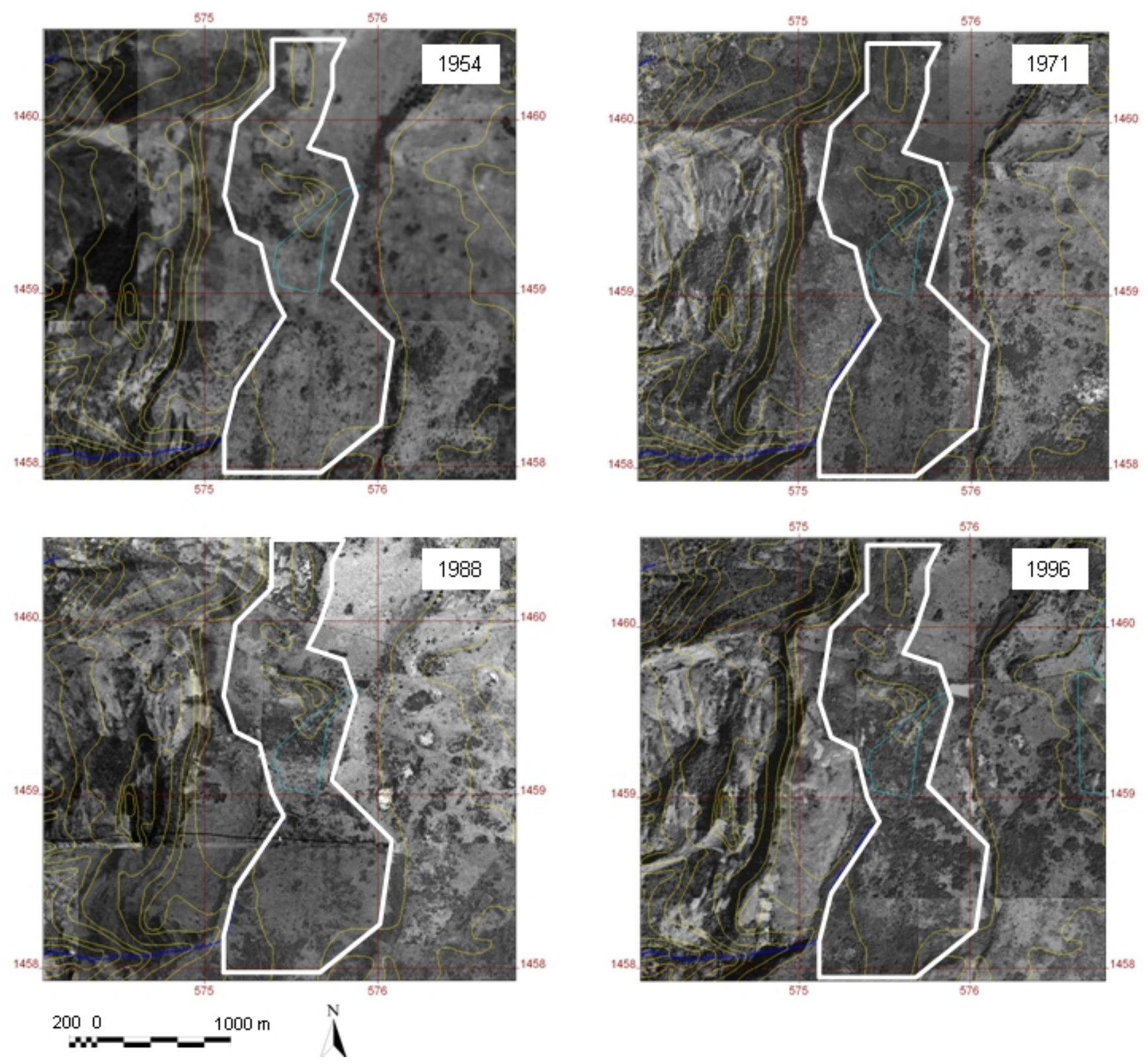

spatial diversity with effects on soil-nutrient cycling (Ravera and Tarrasón, unpublished data), altered soil food-web composition through herbicide and pesticide use (Wardle et al. 1998), and enhances soil erosion under conditions of extremely strong rainfall and recurrent drought (Stocking and Murnaghan 2001). This affects the stability of production and, consequently, the ability of local household economies to adapt to change. Moreover, this agricultural intensification has increased farmers' dependency on inputs while reducing their capacity to handle debt in times of economic crisis. 
Third, "dry forest lands" are currently degraded and fragmented. This is because of a range of historical forces, including population pressure and changes in agrarian systems. Interview results suggest that, despite new protective rules, the inefficacy of the local governance system has increased the disturbance of dry forests over time. In fact, grazing pressure, firewood extraction, accidental fires, and tree harvesting have increased, and this has reduced natural regeneration rates and tree growth (Tarrasón et al. 2010). Local perceptions confirm observations in the literature (Intergovernmental Panel on Climate Change 2007) that dry forests are currently more exposed to drier conditions and extreme events (e.g., intense drought) at individual (e.g., phenology), communitarian (e.g., distribution, interactions), and ecosystem levels (e.g., water storage) than in the past. However, a renewed sense of belonging has led to an increase in environmentally friendly practices, and this may help decrease future forest degradation (Tarrasón et al. 2010) in the area.

\section{Socioeconomic ability of individuals to adapt to change}

In the study region, the extent to which individuals have access to assets that allow them to adapt to change was sharply divided between commercial economies, as opposed to household economies, that is, small farmers, agropastoral, and landless peoples. Key interactions in this system are highlighted in the blue box of Fig. 3. The two types of economies correspond to different objectives and strategies of resource allocation and land management, i.e., maximization of profit and investments as opposed to minimization of risk and food-security maintenance. Individual and household decisions impact the intensity of disturbance that accelerates or slows down the ecological processes of land degradation. Over the past five decades, government policies have favored intensification, and this has reduced the diversity of agricultural commodities being produced in the region (Table 1). Concurrently, local socioeconomic structures have favored land concentration and this has displaced the poorest people onto less productive lands. Paradoxically, although small farmers had obtained access to land through the agrarian reform of the 1980s, they have quickly lost the financial assets to keep these lands productive, and many farmers have fallen under growing debt burdens (Baumeister 2001, Dufumier 2004). Although cattle stocks have increased both locally and nationally for the last two decades (Food and Agriculture Organization 2009a), the cattle raisers' investment capacity has stagnated, and weak organizations have undermined the ability of both commercial and household economies to respond to market dynamics. This has prevented technological innovations from being adopted and has resulted in unequal access to wealth, weakening the ability of individuals to cope with crises (Ravnborg 2003). Interviews show that the most vulnerable households are those composed of elderly parents, single-parent women, or young, landless people who work in the commercial economy. These groups have limited access to land and natural resources such as water and firewood, and lack human, physical, and financial assets, such as wages, animals, technology, and credit.

The perception analysis demonstrates that, historically, local people have shown evidence of mechanisms to cope with risk as a regular component of ongoing management (Table 2). Social capital has also played a key role in supporting the ability of individuals to cope with crises, especially food shortages. However, both individual and collective coping mechanisms, drawing on social networks, have changed and have been eroded in recent years. First, several drivers have affected the extent to which people trust their social contacts. Second, the crisis of household economies has affected initiatives to sustain local management and livelihoods. This has increased the permanent out-migration of local young people to urban areas and foreign countries as a short-term coping response. Demographic changes have meant that the productive population is dwindling, and this itself is driven by poor job opportunities, local living conditions, household indebtedness, and the attraction of an urban lifestyle. Consequently, a renewal in leadership and the long-term ability of individuals to buffer themselves from crisis have been affected.

\section{Institutional capacity to buffer and respond to crisis}

Over time, a lack of coordination across administrative levels has resulted in there being little in place in the way of disaster planning or earlywarning systems in the region. This problem has been widely studied in the literature over different periods (Pyner and Strachan 1976, Biondi-Morra 1993, Sahley et al. 2005). The drivers of change for each historical period are summarized in Table 1. As a result, extreme-weather events, such as 
Table 2. Local mechanisms to cope with disturbance in the study area.

Productive mechanisms:

- transhumance migration systems of animals and people between semiarid and lowlands or humid areas

- renting of farmland in the humid area to extend the growing season, to minimize risk of losses (the "apante" is the growing season during the dry period)

Land-use changes and resources management mechanisms:

- agropastoral diversification and management to reduced impact of market volatility

- preservation of traditional seed varieties to maintain a range of resistance characteristics

- retaining easily disposable assets, such as small livestock, to be sold during times of stress

Labor allocation and intensification mechanisms:

- temporary migration, both seasonal to obtain cash, and to urban or foreign areas for remittance

- allocation of work within the extended family

Collective mechanisms:

- a sharing system ("a media" means "to share") in which landowners either rent grazing land in the dry season in exchange for half the milk production or dung, or purchase inputs for sharecroppers who provide labor

- in-kind transfers of goods and services between farmers

- family and social networks as a source of food or cash in crisis periods (e.g., seeds gathering by landless people during the dry season when landowners' cattle has migrated)

- informal markets of dairy products through social networks in the town

Destitution mechanisms:

- permanent out-migration

- borrowing food and money from merchant and financial organizations at high rates of interest

- transfer of capital stock to financial capital (i.e., selling animals or land)

Hurricane Mitch (1998), extreme droughts (such as in 2001 and 2005), and socioeconomic shocks, such as the global economic crisis (2007-2008; Food and Agriculture Organization $2009 \mathrm{~b}$ ), have all resulted in famine in this region. In particular, decentralization programs have failed to build human capacity and enhance investments, and this has disempowered local governments (Martí i Puig 2004). Moreover, the World Bank's welfare programs, implemented by a neoliberal government to act as buffer for food security, have been ineffective (Sahley et al. 2005). Similarly, cooperative unions, small farmers' syndicates, and historically powerful ranchers unions, have all shown internal divisions at national and local levels since the collapse of the cooperative system, and have been unable to respond to crises. The state's incapacity to coordinate and handle crisis relief has been partly offset by NGOs that have played a key role in reinforcing social safety nets and providing assistance in crisis-stricken areas. On the other hand, the activities of NGOs have reinforced a dependency amongst locals on these programs
(Sahley et al. 2005). Recently, the new socialist central government has implemented a commandand-control regime of natural resource management and food production, distribution, and storage. This has been criticized as it overlaps with local community authorities and risks undermining social relations (Muñoz 2007). At the local level, new schemes and rules around the use of and access to natural resources implemented in protected areas (e.g., fire bans, restrictions on agrochemical use, restrictions on logging activities), have triggered new resource-based conflicts (Nygren 1999, Ravnborg 2008). According to interviewees, the comanagement framework still lacks transparency and legitimacy. Consequently, local tensions have increased, resulting in a loss of trust and the fragmentation of social ties. This has created a vicious cycle: the erosion of social networks has destroyed informal exchanges of goods and services, and this exacerbates social conflicts. The red box in Fig. 3 demonstrates the current links in this dimension of vulnerability. 


\section{Summary of trends in current vulnerability}

Taken together, the degradation of the landscape, driven by both land abandonment and intensification; the loss of assets available to poorer households, driven by economic changes and agricultural specialization; and a reduction in the capacity of formal institutions to provide an effective social buffer or safety net, suggests that the vulnerability of livelihoods in this region has increased. From this, we may infer that future climatic and socioeconomic perturbations, such as drought events or financial crises, may have a commensurately larger impact than past ones.

\section{Future Vulnerability Scenarios}

Researchers and local stakeholders jointly developed scenarios for 2030 to reflect how livelihood vulnerability may change due to future multiple drivers in this agropastoral system. The main socioeconomic components of the four scenarios suggested by the stakeholders are summarized in Table 3, and their short storylines appear in Appendix 3.

In particular, local stakeholders were asked to debate a range of possible adaptation strategies to the added stress of increasing the annual mean temperature by $3.5^{\circ} \mathrm{C}$, as compared with the 1980 99 average, by 2050 , accompanied by a shift in seasonality and a high variability in the intensity of rainfall events (Fig. A.1.2, Appendix 1). The likely indirect impacts of this projection are summarized, based on an extensive literature review (Appendix $1)$.

1. Scenario I. Managing the desert: This is the "business as usual" scenario. Stakeholders agreed that the socioeconomic forces observed in the last decade would continue under this scenario. Adding the stresses of climate change would, in their opinion, increase pressure on natural resources, e.g., more variable rainfall and extreme-weather events would add pressure to abandon certain land areas and intensify agriculture on other land areas, possibly leading to an increase in mismanaged land areas. The current global economic crisis would reduce households' self-reliance and result in commercial and economic stagnation. Participants were worried that, taken together, this would lead to sudden and irreversible shifts in ecosystem states, e.g., changes in grass/bush boundaries. Furthermore, economic opportunities for the rural poor would likely shrink, while income inequities would increase. This would result in a loss of assets and livelihood buffers, thus increasing the downward spiral of outmigration, a destabilized local demography, and new conflicts over critical resources, fresh water for example. Failed local governance would lead to increasingly frail safety nets and a high dependence on external aid.

2. Scenario II. Community-based protectionism: This scenario results in contradictory tendencies among different dimensions of vulnerability. It postulates what might happen if the government were to subsidize food self-sufficiency and community development. Stakeholders suggested that this could lead to conservative ecological practices being implemented to cope with climate change. Although such policies would favor enhanced agroecosystem resilience, these policies would also likely result in subsidized forestry activities and, this, in addition to the increase in crop land, would result in declining herd stocks and abandoned or fragmented rangelands. Therefore, the contradictory impact of these factors on agroecosystem resilience, in combination with climate change, is uncertain. Community-development projects would improve collective coping mechanisms, such as familiar and social networks, and this would enhance community resilience to climate change. However, as the state and local community would take more control over land from large-scale landowners and powerful families, new social conflicts would be expected to arise. Furthermore, it is expected that rules and organization levels for the purpose of achieving community control over resources would be uncoordinated, and this means that institutions would be unlikely to provide effective crisis relief.

3. Scenario III. Development with conservation: This scenario hypothesizes that people might start to promote low-input technologies and that agropastoral system management would shift to protect native vegetation. Stakeholders agreed on suggesting processes through 


\section{Table 3. Overview of the main differences between drivers/components of the four participatory} socioeconomic scenarios for the area for 2030.

\begin{tabular}{|c|c|c|c|c|}
\hline Components & I. Business as usual & $\begin{array}{l}\text { II. Community-based } \\
\text { protectionism }\end{array}$ & $\begin{array}{l}\text { III. Development and } \\
\text { conservation }\end{array}$ & IV. Progress and technology \\
\hline $\begin{array}{l}\text { National } \\
\text { conjuncture }\end{array}$ & $\begin{array}{l}\text { Global and national } \\
\text { instability }\end{array}$ & $\begin{array}{l}\text { Political and } \\
\text { socioeconomic stability }\end{array}$ & $\begin{array}{l}\text { Social and political } \\
\text { stability }\end{array}$ & $\begin{array}{l}\text { Political stability and } \\
\text { socioeconomic instability }\end{array}$ \\
\hline $\begin{array}{l}\text { Market dynamics } \\
\text { and international } \\
\text { treaties }\end{array}$ & $\begin{array}{l}\text { Volatile markets without } \\
\text { state control }\end{array}$ & $\begin{array}{l}\text { Protectionism } \\
\text { Economic treaties within } \\
\text { alternative commercial } \\
\text { alliances in Latin America }\end{array}$ & $\begin{array}{l}\text { New international } \\
\text { partnerships and trade } \\
\text { agreements with EU, USA, } \\
\text { Latin American countries }\end{array}$ & $\begin{array}{l}\text { Free trade agreement with } \\
\text { EU and USA }\end{array}$ \\
\hline $\begin{array}{l}\text { Macroeconomic } \\
\text { and sectoral } \\
\text { policies }\end{array}$ & $\begin{array}{l}\text { Structural Adjustment } \\
\text { Programs } \\
\text { Absent sectoral policies for } \\
\text { rural areas }\end{array}$ & $\begin{array}{l}\text { Subsidized social programs } \\
\text { and } \\
\text { restrictive environmental } \\
\text { plans, organic agriculture } \\
\text { programs }\end{array}$ & $\begin{array}{l}\text { Service-sector } \\
\text { development (e.g., } \\
\text { tourism), sustainable } \\
\text { organic agriculture } \\
\text { programs, environmental } \\
\text { policies }\end{array}$ & $\begin{array}{l}\text { Free competition and } \\
\text { economic deregulation }\end{array}$ \\
\hline External agents & $\begin{array}{l}\text { Role of state limited to } \\
\text { poverty alleviation } \\
\text { programs and food relief }\end{array}$ & $\begin{array}{l}\text { International funding } \\
\text { supports conservation } \\
\text { programs and active } \\
\text { research institutes }\end{array}$ & $\begin{array}{l}\text { International funds } \\
\text { promote rural initiatives, } \\
\text { e.g. microcredit, and active } \\
\text { research institutes }\end{array}$ & $\begin{array}{l}\text { Foreign entrepreneurial } \\
\text { investment }\end{array}$ \\
\hline $\begin{array}{l}\text { Development } \\
\text { initiatives/income } \\
\text { sources }\end{array}$ & $\begin{array}{l}\text { Agriculture retracts due to } \\
\text { global prices/markets for } \\
\text { rural commodities } \\
\text { Wealth stratification }\end{array}$ & $\begin{array}{l}\text { Community /cooperative } \\
\text { agropastoral initiatives } \\
\text { Few entrepreneurs and } \\
\text { little investment }\end{array}$ & $\begin{array}{l}\text { Job diversification } \\
\text { Product diversification } \\
\text { Ecotourism promoted by } \\
\text { entrepreneurs } \\
\text { Payment for ecosystem } \\
\text { services }\end{array}$ & $\begin{array}{l}\text { Agroindustrial development } \\
\text { Economic growth for } \\
\text { commercial ranchers and } \\
\text { wealth stratification }\end{array}$ \\
\hline Local governance & $\begin{array}{l}\text { Local corruption, lack of } \\
\text { transparency, weak trade } \\
\text { unions }\end{array}$ & $\begin{array}{l}\text { Reinforced local } \\
\text { organizations } \\
\text { Effective environmental } \\
\text { protection, control, and } \\
\text { monitoring }\end{array}$ & $\begin{array}{l}\text { Reinforced trade unions } \\
\text { and partnerships } \\
\text { Upgraded systems for } \\
\text { monitoring and controlling } \\
\text { environmental protection }\end{array}$ & $\begin{array}{l}\text { Strong trade unions among } \\
\text { commercial ranchers } \\
\text { Weak local monitoring and } \\
\text { control of environment }\end{array}$ \\
\hline $\begin{array}{l}\text { Distribution of/ } \\
\text { access to land, } \\
\text { natural resources, } \\
\text { and capital }\end{array}$ & $\begin{array}{l}\text { Progressive land } \\
\text { abandonment } \\
\text { Proletarization, } \\
\text { marginalization } \\
\text { Limited access to land and } \\
\text { natural resources }\end{array}$ & $\begin{array}{l}\text { Land redistribution/ } \\
\text { regulation (prevalence of } \\
\text { small farming systems and } \\
\text { household economies) } \\
\text { National top-down control } \\
\text { for guaranteeing access to/ } \\
\text { use of natural resources }\end{array}$ & $\begin{array}{l}\text { Land regulation, presence } \\
\text { of different typologies of } \\
\text { commercial and household } \\
\text { economies } \\
\text { New local arrangements } \\
\text { and rules for guaranteeing } \\
\text { equal access and use of } \\
\text { natural resources }\end{array}$ & $\begin{array}{l}\text { Land concentration } \\
\text { (deregulated and liberalized } \\
\text { land markets) } \\
\text { Unequal access to natural } \\
\text { resources }\end{array}$ \\
\hline $\begin{array}{l}\text { Land use and } \\
\text { management }\end{array}$ & $\begin{array}{l}\text { Monofunctional land use } \\
\text { (pastoral use) and } \\
\text { intensification } \\
\begin{array}{l}\text { Agropastoral and dry forest } \\
\text { degradation }\end{array}\end{array}$ & $\begin{array}{l}\text { Monofunctional land use } \\
\text { (agropastoral use) } \\
\\
\text { Expansion of subsistence } \\
\text { cultivation systems } \\
\text { (traditional and } \\
\text { agroecological low external } \\
\text { inputs agriculture) and } \\
\text { reforestation/ } \\
\text { regeneration practices }\end{array}$ & $\begin{array}{l}\text { Multifunctional land-use } \\
\text { innovations in agropastoral } \\
\text { systems management with } \\
\text { agroecological semi- } \\
\text { intensification (low } \\
\text { external inputs agriculture } \\
\text { and forest regeneration/ } \\
\text { conservation practices) }\end{array}$ & $\begin{array}{l}\text { Monofunctional land use } \\
\text { (pastoral use) } \\
\text { High external inputs } \\
\text { agriculture (intensification) } \\
\text { Dismantled subsistence } \\
\text { systems }\end{array}$ \\
\hline
\end{tabular}




\begin{tabular}{|c|c|c|c|c|}
\hline Labor market & $\begin{array}{l}\text { Economic stratification and } \\
\text { labor exploitation persist, } \\
\text { high out-migration }\end{array}$ & $\begin{array}{l}\text { Few or moderate } \\
\text { opportunities in rural areas }\end{array}$ & $\begin{array}{l}\text { New job opportunities in a } \\
\text { wide range of agricultural } \\
\text { and service sectors }\end{array}$ & $\begin{array}{l}\text { Only agrarian workers } \\
\text { Few alternative } \\
\text { opportunities in mechanized } \\
\text { rural economies }\end{array}$ \\
\hline Social cohesion & $\begin{array}{l}\text { Low community spirit / } \\
\text { workers' moral } \\
\text { Social and political } \\
\text { conflicts over land and } \\
\text { natural resources }\end{array}$ & $\begin{array}{l}\text { Strong community-based } \\
\text { protectionism among } \\
\text { landless people }\end{array}$ & $\begin{array}{l}\text { Collaboration and } \\
\text { partnerships among local } \\
\text { users and trade unions }\end{array}$ & $\begin{array}{l}\text { Competitiveness and } \\
\text { individualism deconstruct } \\
\text { social ties }\end{array}$ \\
\hline \multirow{3}{*}{$\begin{array}{l}\text { Culture, values, } \\
\text { lifestyle }\end{array}$} & Persistent corruption & Historical coping strategies & New rural lifestyle & Weak sense of belonging \\
\hline & $\begin{array}{l}\text { Resistance to change } \\
\text { among local traditional } \\
\text { large landowners }\end{array}$ & Strong sense of belonging & $\begin{array}{l}\text { New sense of belonging } \\
\text { (e.g., brand and green } \\
\text { culture) }\end{array}$ & $\begin{array}{l}\text { Urban lifestyle attracts } \\
\text { people in rural areas }\end{array}$ \\
\hline & $\begin{array}{l}\text { Youth preference for urban } \\
\text { lifestyle }\end{array}$ & & & \\
\hline $\begin{array}{l}\text { Infrastructure and } \\
\text { technology }\end{array}$ & Absence of investment & $\begin{array}{l}\text { Investments in agricultural } \\
\text { extension programs }\end{array}$ & $\begin{array}{l}\text { Investment in green } \\
\text { management practices } \\
\text { (low-input technology) }\end{array}$ & $\begin{array}{l}\text { High levels of private } \\
\text { investment in technology } \\
\text { and infrastructure }\end{array}$ \\
\hline
\end{tabular}

which these strategies could enhance functional diversity, productivity, and incomes. In addition, investments in building environmental awareness in rural areas could be directed to support entrepreneurial initiatives that include local communities participating in private and communal projects. Smallholder farmers would receive incentives to develop small-scale production outside mainstream business contracts. New alliances among local stakeholders, trade unions, and institutions would create longterm opportunities and facilitate capacity building with farmers, resulting in innovation and learning through experimentation. Finally, political and social stability, e.g., more equitable land-tenure access and transparent regularization, could improve local governance.

4. Scenario IV. Progress and technology: In this scenario, stakeholders discussed how agroindustrial development could improve both biophysical and socioeconomic conditions. Conflicting perceptions emerged, and unclear and unpredictable cause-effect relationships were debated. Stakeholders agreed that innovations in green technology could enhance land productivity and would likely be ecologically friendly and economically efficient. However, other stakeholders argued that such innovations could have unexpected impacts, and would likely only be beneficial during climatically "normal" years because, as agroecosystems become more intensively managed, they would be more sensitive to drought and other climatic stresses. This would likely benefit commercial ranchers who have huge land holdings (and are thus protected from small-scale climatic problems), and they would be able to increase their assets, leading to greater inequities and conflict. This would create a further feedback with mechanized agriculture reducing the demand for labor, thus increasing migration and dismantling social mechanisms that buffer poor households against food insecurity. Thus, safety nets would be driven by private and external aid support, resulting in high levels of uncertainty about the accountability and transparency of local governance.

Summary of trends in future vulnerability and adaptation

The implications for vulnerability to multiple stresses (Fig. 5) are summarized as follows: 
1. Under scenario $I$, in terms of future agroecological resilience, the ability of individuals to adapt and the capacity of institutions to provide buffers will diminish. Uncertainty about the trends is low, and primarily related to either ignorance or incomplete information and knowledge with regard to the extent of possible changes.

2. Under scenario II, it is unclear whether agroecological resilience will rise or fall. The assets available to individuals will likely increase for household-level economies, whereas commercial landowners will redistribute assets. The capacity of institutions to respond to crisis will increase, but with high levels of unpredictability due to possible contradictions about the effects of a neosocialist system.

3. In scenario III, all three dimensions of vulnerability appear to be set to improve. Uncertainty about trends is low, and there is a confluence of visions with regard to the effects of drivers.

4. The final scenario (IV) has unclear and conflicting implications regarding all three dimensions.

As a final point, the consequences of different development pathways visualized in a systematic way helped local stakeholders to design a multiscale bundle of strategies across these different scenarios (Table 4).

\section{FINAL REMARKS}

\section{Empirical Remarks about the Drivers of Vulnerability}

This study focuses on understanding the key driving forces behind changes in semiarid agropastoral systems in Nicaragua, providing some evidence of a larger picture of future vulnerability and suggestions with regard to adaptive strategies across space and time.

\section{Economic forces and the uncertain environment}

The literature shows that both global environmental and economic changes have an effect on livelihood vulnerability (O'Brien and Leichenko 2000, Stringer 2009). Therefore, anticipating future vulnerability in semiarid environments must take into account varying degrees of ecological and socioeconomic uncertainty. Our analysis shows that historical inequities in land and wealth distribution were driven by macroeconomic policies, and this affected the local management of natural resources. In terms of how this may play out in the future, both scenarios I and IV suggest that inequities may contribute to the continued destitution of small farmers, and this may increase vulnerability (Ohlsson 2000) and environmental degradation (Rahman 2004). The study also suggests that the relationships among resilience, economic policies, and instability, are complex. Historically, incentives that stimulated both commercial farmers in the 1960s and cooperatives in the 1980s disrupted important local-level social-ecological functions (Kaimowitz 1997). Top-down agricultural policies may erode ecological resilience even where political conditions are stable (Fraser and Stringer 2009). Conversely, in unstable situations, such as in neoliberal regimes, land abandonment, short-term investments, and opportunistic behaviors in landowners are common (Albers and Goldbach 2000). Finally, the research presented here shows that when local economies depend on few resources and activities, they are vulnerable to the "boom and bust" nature of markets (Adger 2000), and this accentuates the likely impact of future climatic variability. In contrast, macroeconomic policies that favor equal access to land and diverse markets that include tourism and fair-trade markets can cushion households during periods of food insecurity. These more optimistic futures are the subject of scenarios II and III.

\section{Leadership, social capital, and the governance system}

This study also confirms the literature (e.g., Folke et al. 2002) by showing how institutional failures disturb local mechanisms for environmental monitoring, and that shifts in governance system can affect the ways communities deal with external shocks. For instance, changes that drove land resettlement undermined the way native pastures were managed and exacerbated vulnerability to drought. To rectify this, an institution-building process can help restore adaptive capacity, and institutions need to empower local groups to experiment, learn, and reflect. (This is addressed by scenario III). Strengthened local leadership, flexible institutions, anti-corruption initiatives, and new 
Fig. 5. (a) Heuristic illustration of trends of vulnerability indicators within the four scenarios, and (b) 3D space representation of the resulting hypothetical pathways from the actual baseline ( $\mathrm{t}=0$ ) to 2030 (adapted from Fraser 2010).

(a)

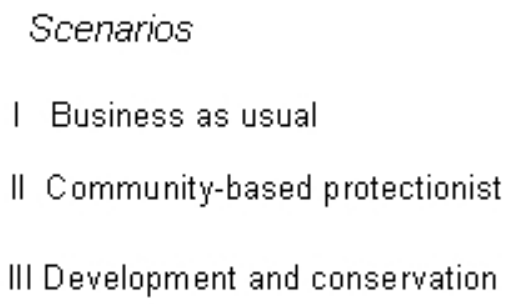

V Progress and technology
Agroecological Individual Institutional

\begin{tabular}{|c|c|c|c|c|c|}
\hline \multicolumn{2}{|c|}{$\downarrow$} & \multicolumn{2}{|c|}{$\downarrow$} & \multicolumn{2}{c|}{$\downarrow$} \\
\hline$\uparrow$ & $\downarrow$ & $\uparrow$ & $\downarrow$ & \multicolumn{2}{|c|}{$\uparrow$} \\
\hline \multicolumn{2}{|c|}{$\uparrow$} & \multicolumn{2}{|c|}{$\uparrow$} & \multicolumn{2}{|c|}{$\uparrow$} \\
\hline$\uparrow$ & $\downarrow$ & $\uparrow$ & $\downarrow$ & $\uparrow$ & $\downarrow$ \\
\hline
\end{tabular}

(b)

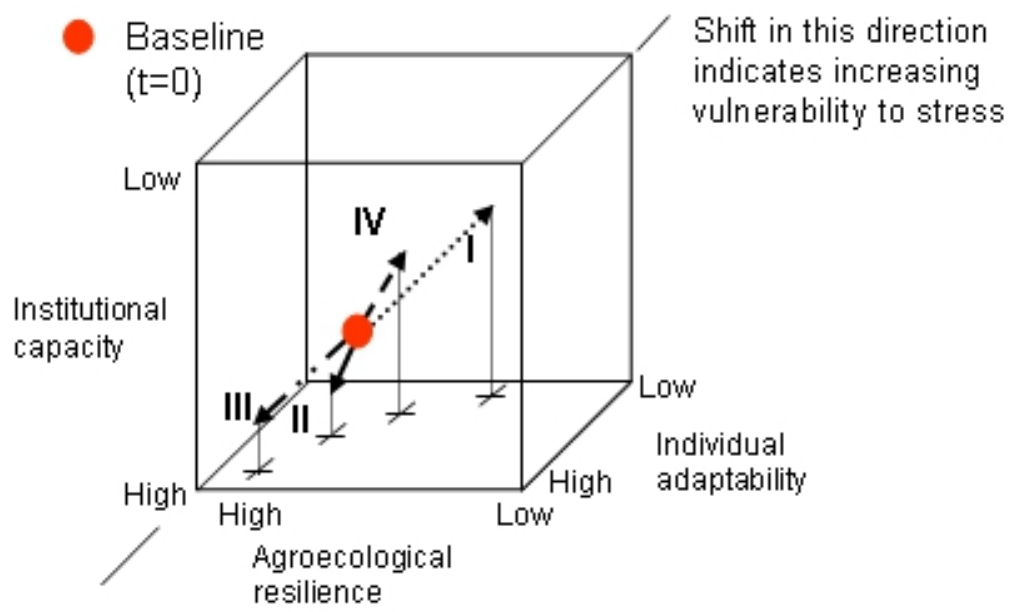

Shift in this direction indicates increasing resilience to stress

Notes: (a) Up arrow: better=no reason for specific concern; down arrow: worse=be alert or warming development. Colors and boldness of the line indicate the degree of uncertainty of the trend (red and bold line for high uncertainty, green and fine line for low uncertainty). (b) If the trends toward opposite directions have different degrees of uncertainty, the arrow depicts a trend with low uncertainty. If the trends toward opposite directions have the same degree of uncertainty, this results in no change of direction from the baseline. 
Table 4. Individual and institutional adaptive strategies and policies proposed by stakeholders, their scale, and dimension of intervention.

\begin{tabular}{lll}
\hline \hline Adaptive strategy & Scale & Dimension \\
\hline $\begin{array}{l}\text { Harmonize institutional planning responses, integrate participatory decision making } \\
\text { processes: }\end{array}$ & $\begin{array}{l}\text { national-regional- } \\
\text { local }\end{array}$ & institutional
\end{tabular}

- decentralization, without deregulation, that creates, strengthens, and delegates power and economic responsibility to local organizations and institutions

- private-public partnerships

Revise international trade policies to improve market access:

nationalinternational

political

- take advantage of existing mechanisms for "local products" and special "safeguard

mechanisms" to protect national agricultural sectors

- establish appropriate food stocks to prevent price volatility

- secure access to information and microcredit

Mechanisms and funding to support rural investments:

- establish appropriate policies to reduce impacts of food-price inflation

- invest in agriculture in low-potential areas as a social investment

- diversify rural on-farm and off-farm economies

- financial compensation for ecosystem-services protection

- infrastructure investments

Strengthen law enforcement for land ownership and rights to natural resources access:

national

political

- secure land rights

- ensure land access for disadvantaged groups

- restrict land sales to foreign investors

Reinforce organizations and networks (governance and adaptive comanagement):

nationalinternational

political

- capacity building for communities to achieve self-sustaining projects

- strengthen alliances and coordination between comanagers (FORO Miraflor), communities,

landowners, ranchers, trade unions, councils, and academic institutions

- enhance market competitiveness, e.g., construct warehouses for crop and dairy products

Farmer-to-farmer knowledge exchange and extension: local-regionalnational

local

local social-institutional

- share good farming practices through the establishment of model farms, and strengthen capacity to monitor and assess

- exchange native crop varieties through local seed fairs

- join national networks, e.g., Farmer-to-Farmer Program; initiatives such as "Seeds for Identity"

- farm-planning design with ten-year timespan

Innovative agricultural practices:

- switch from monoculture to diversified agriculture: use traditional maize-bean

intercropping system, cultivar rotation with green manure or farm-cattle manure

- technological innovation (low energy input) to produce quality dairy products

- equilibrate nutrient flows through integrated management with mixed-farming systems,

crop-pasture nutrient management

- improve livestock systems with rotational grazing systems, fodder bank for livestock,

fodder tree in paddocks

- support on-farm experiments with rotational livestock and protein banks

Dry forest conservation programs:

- reforestation with local species for vulnerable and exposed areas

- planned natural regeneration

- development of management guidelines environmentalproductive local-regional social-institutional 
Water-system technologies:

- small-scale water management solutions, i.e., rainwater harvesting techniques, tanks

- water retention in soil, through innovative agricultural practices

Alternative energy sources:

- create communal "energy forest" to supply fuel wood without threatening remaining dry forest

- develop wind power

Communication plans:

- transfer technical and scientific knowledge to local stakeholders

- coordinate early warning systems and disaster risk programs

- coordinate between comanagers and councils to enhance their prevalence in the area

(strengthen the efficacy of local rules)

Investigate feasibility of ecotourism:

- create and train a tourism commission local-regional

local-regionalnational

local

local-national social-

institutional-

environmental

social-

institutional-

environmental

social-institutional forms of social networks and collaboration would all enhance overall resilience and reduce the dependence on external aid while increasing safety nets. Therefore, this research suggests that neither centralization nor decentralization are appropriate, but that cross-level interactions may lead to a sharing of management power and responsibility. This calls for a transparent and interactive commitment across decision-making scales and new forms of integrated policies (Intergovernmental Panel on Climate Change 2007).

\section{Cultural drivers}

Local institutional arrangements and land-use behavior are deeply influenced by cultural values. Historical evidence and future scenarios illustrate how international lifestyles and values have changed (e.g., consumer demand for green products) and have influenced land use and management. For example, technological innovations in conventional agroindustry (scenario IV) are perceived to boost rural development and improve living standards for some, while aggravating social inequities. In contrast, the technological changes discussed in scenarios II and III are more socially inclusive. Providing funding that supports ecosystem-services management (Goldman et al. 2008) is an illustration of this, and has been used to combat poverty and enhance nature conservation (Hecht 2004). However, these programs have failed to recognize the roles of the agropastoral system as a provider of ecosystem services (Pagiola et al.
2007) and to support subsistence farmers as conservationists. Therefore, there is a need to develop new context-specific strategies that value knowledge exchanges among local stakeholders and researchers.

\section{Methodological Remarks about Studying Vulnerability}

Reflecting on the process undertaken to conduct this research, we have highlighted some theoretical and methodological challenges concerning vulnerability assessments. First, we have demonstrated that conceptual modeling and participatory scenario development can be powerful tools for bringing knowledge systems together, empowering local stakeholders to distinguish opportunities and threats, and enabling negotiation. Second, overlapping the baseline conceptual model with future scenarios and climatic stress allowed us to creatively imagine a proactive and anticipatory, rather than reactive, adaptation window. Framing interrelated drivers and factors into the three dimensions of vulnerability is a manageable format for dealing analytically with multidimensional assessments of vulnerability to change, and helps to identify critical components for making the system more vulnerable or resilient. Finally, we have found that integrated methodological frameworks can deepen our understanding of semiarid livelihood systems as a whole, and our comprehension of hypothetical factors that may reinforce or weaken 
their vulnerability (Knutsson and Ostwald 2006). Additionally, the proposed framework has enabled a comparison between cases to extract broader lessons on multiple facets of change in complex regional social-ecological systems, such as the semiarid agropastoral systems in the Central American dry corridor. In conclusion, the proposed framework of assessment has demonstrated a tool that is helpful for planning processes, for exploring possible future pathways and negotiating the key components of scenarios that can help to prioritize adaptation decisions. However, the vulnerability assessment needs further refinement. Further research will focus on defining irreversibility in maintaining resilience when indicator thresholds are passed, and on building interfaces between social research and mathematical modeling, both theoretically and practically.

Responses to this article can be read online at: http://www.ecologyandsociety.org/vol16/iss 1/art20/ responses/

\section{Acknowledgments:}

We acknowledge two anonymous reviewers for their comments. A special thanks to Evan Fraser for his rigorous review and editing and to Jan Sendzimir, Mark Reed, and Claire Quinn for their constructive suggestions. We would like also to recognize the communities and landowners from the study area who participated actively in the research. We are grateful to colleagues from FAREM-Estelí (Nicaragua) for their support in interviews and field work. Funding for this research was provided by Catalan Agency for Development Cooperation (ACCD). We also acknowledge Natural Environment Research Council's (UK) Quantifying and Understanding the Earth System (QUEST) Global Scale Impacts project and the Centre for Climate Change Economics and Policy, University of Leeds. The writing of this paper was enabled through funds from the Marie Curie Early Stage Training fellowship from European Centre for Biodiversity and Conservation Research (BIOCONS), funds for a postdoctoral fellowship from the Agency for Administration of University, and Research Grants of the Catalan Government (AGAUR).

\section{LITERATURE CITED}

Adger, N. 2000. Social and ecological resilience: are they related? Progress in Human Geography 24:347-364. [online] URL: http://phg.sagepub.com/ cgi/content/abstract/24/3/347.

Albers, H. J., and M. J. Goldbach. 2000. Irreversible ecosystem change, species competition, and shifting cultivation. Resource and Energy Economics 22:261-280.

Barnett, J., and N. W. Adger. 2007. Climate change, human security and violent conflict. Political Geography 26:638-655.

Battisti, D. S., and R. L. Naylor. 2009. Historical warnings of future food insecurity with unprecedented seasonal heat. Science 323:240-244.

Baumeister, E. 2001. Peasant initiatives in land reform in Central America. Pages 65-85 in K. B. Ghimire, editor. Land reform and peasant livelihoods: the social dynamics of rural poverty and agrarian reforms in developing countries. ITDG Publishing, London, UK.

Biondi-Morra, B. N. 1993. Hungry dreams: the failure of food policy in revolutionary Nicaragua. 1979-90. Cornell University Press, London, UK.

Christensen, J. H., T. R. Carter, M. Rummukainen, and G. Amanatidis. 2007. Evaluating the performance and utility of regional climate models: the PRUDENCE project. Climatic Change 81:1-6.

Corbett, J. 1988. Famine and household coping strategies. World Development 16(9):1099-1112.

Dufumier, M. 2004. Agricultures et paysanneries des tiers mondes. Karthala, Paris, France.

Eriksen, S., and K. O'Brien. 2007. Vulnerability, poverty and the need for sustainable adaptation measures. Climate Policy 7(4):337-352.

Folke, C., C. S. Holling, and C. Perrings. 1996. Biological diversity, ecosystems and the human scale. Ecological Applications 6(4):1018-1024.

Folke C., S. Carpenter, T. Elmqvist, L. Gunderson, C. S. Holling, B. Walker, J. Bengtsson, F. Berkes, J. Colding, K. Danell, M. Falkenmark, L. Gordon, R. Kasperson, N. Kautsky, A. Kinzig, S. Levin, K- 
G. Mäler, F. Moberg, L. Ohlsson, P. Olsson, E. Ostrom, W. Reid, J. Rockström, H. Savenije, and U. Svedin. 2002. Resilience and sustainable development: building adaptive capacity in a world of transformations. Report for the Swedish Environmental Advisory Council. 2002:1. Ministry of the Environment, Stockholm, Sweden.

Food and Agriculture Organization (FAO). 2004. Assessment of the world food security situation. Background document, 30th session of the Committee on World Food Security, 20-23 September 2004, Rome, Italy. [online] URL: http:// www.fao.org/unfao/bodies/cfs/cfs30/cfs2004 en.htm

FAO. 2009a. FAOSTAT data. Rome, Italy. [online] URL: http://faostat.fao.org/site/573/default.aspx\#ancor

FAO. 2009b. The state of agricultural commodity markets 2009. High food prices and the food crisis - experiences and lessons learned. Report to the FAO, Rome, Italy. [online] URL: http://www.fao.o $\mathrm{rg} / \mathrm{docrep} / 012 / \mathrm{i} 0854 \mathrm{e} / \mathrm{i} 0854 \mathrm{e} 00 . \mathrm{htm}$.

Fraser, E. D. G. 2007. Travelling in antique lands: using past famines to develop an adaptability/ resilience framework to identify food systems vulnerable to climate change. Climatic Change 83:495-514.

Fraser, E. D. G., and L. C. Stringer. 2009. Explaining agricultural collapse: macro-forces, micro-crisis and the emergence of land use vulnerability in southern Romania. Global Environmental Change 19(1):45-53.

Fraser, E., A. J. Dougill, K. Hubacek, C. H. Quinn, J. Sendzimir, and M. Termansen. 2011. Assessing vulnerability to climate change in dryland livelihood systems: conceptual challenges and interdisciplinary solutions. Ecology and Society, in press. Fussel, H. M., and R. T. J. Klein. 2006. Climate change vulnerability assessments: an evolution of conceptual thinking. Climatic Change 75(3):301-329.

Gallopin, G.C. 2006. Linkages between vulnerability, resilience, and adaptive capacity. Global Environmental Change 16:293-303.
Gee, J. P. 1999. An introduction to discourse analysis: theory and method. Routledge, New York, New York, USA.

Gibson, B. 1996. The environmental consequences of stagnation in Nicaragua. World Development 24 (2):325-339.

Giménez, A. 2006. Climate change and variability in the mixed crop/livestock production systems of the Argentinean, Brazilian and Uruguayan Pampas. Final report to Assessments of Impacts and Adaptations to Climate Change (AIACC). Instituto Nacional de Investigación Agropecuaria, International START Secretariat, Washington, D.C., USA.

Goldman, R. L., H. Tallis, P. Kareiva, and G. C. Daily. 2008. Field evidence that ecosystem service projects support biodiversity and diversify options. Proceedings of the National Academy of Sciences 105:9445-9448.

Halpin, P. N., P. M. Kelly, C. M. Secrett, and T. M. Schmidt. 1995. Climate change and Central America forest system. Background paper on the Nicaragua pilot project: report of working group II: impacts, adaptation and vulnerability. Intergovernmental Panel on Climate Change, Geneva, Switzerland.

Hecht, S. 2004. Invisible forests: the political ecology of forest resurgence in El Salvador. Pages 64-104 in R. Peet, and M. Watts, editors. Liberation ecologies: environment, development, and social movements. Routledge, London, UK.

Hertel, T. W., M. B. Burke, and D. B. Lobell. 2010. The poverty implications of climate-induced crop yield changes by 2030. Global Environmental Change20(4):577-585.

Holling, C. S. 1986. Resilience of ecosystems, local surprise and global change. Pages 292-317 in W. C. Clark, and R. E. Munn, editors. Sustainable development of the biosphere. Cambridge University Press, Cambridge, UK.

Holling, C. S., L. Gunderson, and G. Peterson. 2001. Sustainability and panarchies. Pages 63-102 in L. H. Gunderson, and C.S. Holling, editors. Panarchy: understanding transformations in human and natural systems. Island Press, Washington, D.C., USA. 
Intergovernmental Panel on Climate Change (IPPC). 1998. Regional impacts of climate change: an assessment of vulnerability. Cambridge University Press, New York, New York, USA.

IPPC. 2007. Climate change 2007: impacts, adaptation and vulnerability. In M. L. Parry, O. F. Canziani, J. P. Palutikof, P. J. van der Linden, and C.E. Hanson, editors. Contribution of working group II to the fourth assessment report of the IPPC. Cambridge University Press, Cambridge, UK.

Kaimowitz, D. 1996. Livestock and deforestation in Central America in the 80s and 90s: a policy perspective. Center for International Forestry Research (CIFOR), Jakarta, Indonesia.

Kaimowitz, D. 1997. Policies affecting deforestation for cattle in Central America. Pages 51-66 in J. P. De Groot, and R. Ruben, editors. Sustainable agriculture in Central America. Palgrave Macmillan, New York, New York, USA.

Knutsson, P., and M. Ostwald. 2006. A processoriented sustainable livelihoods approach - a tool for increasing understanding of vulnerability, adaptation and resilience. Mitigation and Adaptation Strategies for Global Change. [online] URL: http://dx.doi.org/10.1007/s11027-006-4421-9

Jones, P. G., and P. K. Thornton. 2003. The potential impacts of climate change on maize production in Africa and Latin America in 2055. Global Environmental Change 13:51-59.

Lobell, D. B., M. B. Burke, C. Tebaldi, M. D. Mastrandrea, W. P. Falcon, and R. L. Naylon. 2008. Prioritizing climate change adaptation needs for food security in 2030. Science 319:607-610.

Magrin, G., C. Gay García, D. Cruz Choque, J.C. Giménez, A. R. Moreno, G. J. Nagy, C. Nobre and A. Villamizar. 2007. Latin America. Climate change 2007: impacts, adaptation and vulnerability. In M. L. Parry, O. F. Canziani, J. P. Palutikof, P. J. van der Linden, and C.E. Hanson, editors. Contribution of working group II to the fourth assessment report of the IPPC. Cambridge University Press, Cambridge, UK.

Marín, Y., and S. Pauwels. 2001. El campesinofinquero II. VLIR-UCA-Nitlapan, Managua, Nicaragua.
Martí i Puig, S. 2004. Tiranías, rebeliones y democracia: itinerarios políticos comparados en Centroámerica. Bellaterra, Barcelona, Spain.

Millennium Ecosystem Assessment. 2005. Ecosystems and human well-being: synthesis report. Island Press, Washington, D.C., USA. [online] URL: http ://www.millenniumassessment.org/documents/ document.356.aspx.pdf.

Muñoz, G. 2007. Vamos a defender los espacios de participación ciudadana que ya existen. Envío 303. [online] URL: http://www.envio.org.ni/articulo/3565

Nayak, P. K. 2004. Building knowledge and facilitating learning through adaptive community forest management. Proceedings of the Tenth Biennial Conference of the International Association for the Study of Common Property. 9-13 August 2004, Oaxaca, Mexico. International Association for the Study of the Commons, Bloomington, Indiana. [online] URL: http://fes.org.in/abstractWo rPap.php?pId=NC0xMy0z.

National Weather Service. 2010. Changes to the Oceanic Niño Index (ONI). National Oceanic and Atmospheric Administration (NOAA), Washington, D.C., USA. [online] URL: http://www.cpc.noaa.gov/ products/analysis monitoring/ensostuff/ensoyears. $\underline{\text { shtml. }}$

Nygren, A. 1999. Local knowledge in the environment-development discourse. Critique of Anthropology 19:267-288.

O’Brien, K. L., and R. M. Leichenko. 2000. Double exposure: assessing the impacts of climate change within the context of economic globalization. Global Environmental Change 10:221-232.

Ohlsson, L. 2000. Livelihood conflicts: linking poverty and environment as causes of conflict. Environmental Policy Unit, Sida, Stockholm, Sweden.

Osbahr, H., C. Twyman, W. N. Adger, and D. S. G. Thomas. 2008. Effective livelihood adaptation to climate change disturbance: scale dimensions of practice in Mozambique. Geoforum 39:1951-1964.

Pagiola, S., E. Ramirez, J. Gobbi, C. De Haan, M. Ibrahim, E. Murgueitio, and J. P. Ruiz. 2007. Paying 
for the environmental services of silvo-pastoral practices in Nicaragua. Ecological Economics 64:374-85.

Patz, J. A., D. Campbell-Lendrum, T. Holloway, and J. A. Foley. 2005. Impact of regional climate change on human health. Nature 438:310-317.

Primavesi, A. 2004. Manejo ecológico de pastagens: em regiões tropicais e subtropicais. Nobel, Sao Paulo, Brazil.

Pyner, G., and C. Strachan. 1976. Nutrition sector assessment for Nicaragua. U.S. Agency for International Development (USAID), Washington, D.C., USA.

Rahman, A. 2004. Environment-poverty nexus: a global overview. Technical Cooperation Project of the United Nations Department for Economic and Social Affairs (UNDESA), Bangkok, Thailand.

Ravera, F., D. Tarrasón, P. Andrés, and R. Grasa. 2009. Evaluación participativa de sostenibilidad en sistemas agrosilvopastoriles semi-áridos: un caso de estudio en Nicaragua. Revista Iberoamericana de Economía Ecológica 13:79-99. [online] http://w ww.redibec.org/IVO/rev13 06.pdf.

Ravnborg, H. M. 2003. Poverty and environmental degradation in the Nicaraguan hillsides. World Development 31:1933-46.

Ravnborg, H. M.. 2008. Organising to protect: protecting landscapes and livelihoods in the Nicaraguan hillsides. Conservation and Society 6 (4): 283-292. [online] URL: http://www.conservat ionandsociety.org/temp/ConservatSoc64283-29166 98 080606.pdf.

Reed, M. S., A. Bonn, K. Broad, P. Burgess, I. R. Fazey, E. D. G. Fraser, K. Hubacek, D. Nainggolan, P. Roberts, C. H. Quinn, L. C. Stringer, S. Thorpe, D. D. Walton, F. Ravera, and S. Redpath. In press. Participatory scenario development for environmental management: a methodological framework. Journal of Environmental Management.

Reynolds, J. F., F. T. Maestre, H. E. Sannwald, J. Herrick, and P. R. Kemp. 2005. Aspectos socioeconómicos y biofísicos de la desertificación. Ecosistemas 2005/3. [online] URL: http://www.rev istaecosistemas.net/articulo.asp? Id=131.
Richardson, F. D., B. D. Hahn, and M. T. Hoffman. 2007. Modeling the sustainability and productivity of pastoral systems in the communal areas of Namaqualand. Journal of Arid Environments 70:701-717.

Rosenzweig, C. E., A. Iglesias, X. B. Yang, P. R. Epstein, and E. Chivian. 2001. Climate change and extreme weather events: implications for food production, plant diseases, and pests. Global Change and Human Health 2(2):90-104.

Rousteenoja, K., T. R. Carter, K. Jylha, and H. Tuomenvirta. 2003: Future climate in world regions: an intercomparison of model-based projections for the new IPCC emissions scenarios. Finnish Environment Institute, Helsinki, Finland.

Sahley, C., B. Crosby, D. Nelson, and L. Vanderslice. 2005. The governance dimensions of food security in Nicaragua. U. S. Agency for International Development, Washington, D.C., USA. [online] URL: http://pdf.usaid.gov/pdf docs/ PNADE106.pdf.

Sala, O. E., F. S. Chapin, J. J. Armesto, E. Berlow, J. Bloomfield, R. Dirzo, E. Huber-Sanwald, L. F. Huenneke, R. B. Jackson, A. Kinzig, R. Leemans, D. M. Lodge, H. A. Mooney, M. Oesterheld, N. L. Poff, M. T. Sykes, B. H. Walker, M. Walker, and D. H. Wall. 2000. Global biodiversity scenarios for the year 2100. Science 287:1770-1774.

Scherr, S. J. 1999. Soil degradation: a threat to developing-country food security by 2020? International Food Policy Research Institute (IFPRI), Washington, D.C., USA.

Scoones, I. 1998. Sustainable rural livelihoods: a framework for analysis. Working paper 72. Institute of Development Studies, University of Sussex, Brighton, UK.

Sen, A. 1991. Poverty and famines: an essay on entitlement and deprivation. Oxford University Press, Oxford, UK.

Sendzimir, J., P. Magnuszewski, Z. Flachner, P. Balogh, G. Molnar, A. Sarvari, and Z. Nagy. 2007. Assessing the resilience of a river management regime: informal learning in a shadow network in the Tisza River Basin. Ecology and Society 13(1): 11. [online] URL: http://www.ecologyandsociety.org/ vol13/iss1/art11/. 
Stocking, M. A., and N. Murnaghan. 2001. Handbook for the field assessment of land degradation. Earthscan, London, UK.

Stringer, L. 2009. Reviewing the links between desertification and food insecurity: from parallel challenges to synergistic solutions. Food Security 1 (2):113-126.

Tarrasón D., J. Urrutia, F. Ravera, E. Herrera, P. Andrés and J. M. Espelta. 2010. Conservation status of tropical dry forest remnants in Nicaragua: Do ecological indicators and social perception tally? Biodiversity and Conservation 19(3):813-827.

United Nations Convention to Combat Desertification (UNCCD). 2004. Compilation of summaries of reports submitted by Latin American and Caribbean countries parties. UNCCD report. ICCD/CRIC (1)/4/Add.2, Rome, Italy. [online] URL: http://www .unccd.int/cop/officialdocs/cric1/pdf/4add2eng.pdf

University of East Anglia Climate Research Unit (CRU). 2008. CRU datasets. British Atmospheric Data Centre, Oxfordshire, UK. [online] URL: http: //badc.nerc.ac.uk/data/cru.

van Aalst MK, T. Cannon, and I. Burton. 2008. Community level adaptation to climate change: the potential role of participatory community risk assessment. Global Environmental Change 18:165179.

Walker, B. H., A. Kinzig, and J. Langridge. 1999. Original articles: plant attribute diversity, resilience, and ecosystem function: the nature and significance of dominant and minor species. Ecosystems 2:95-113. [online] URL: http://dx.doi. org/10.1007/s100219900062.

Walker, B. H., and N. A. Abel. 2001. Resilient rangelands: adaptation in complex systems. Pages 293-314 in L. Gunderson, and C. S. Holling, editors. Panarchy: understanding transformations in human and natural systems. Island Press, Washington, D.C., USA.

Wardle, D. A., H. A. Verhoef, and M. Clarholm. 1998. Trophic relationships in the soil microfood web: predicting the responses to a changing global environment. Global Change Biology 4(7):713727.

World Food Program (WFP). 2002. Standardized food and livelihood assessment in support of the Central American PRRO (draft). WFP, Managua, Nicaragua. 
APPENDIX 1. Climatic trends.

The analysis of historical trends in annual temperature and precipitation was based on monthly data observed for the period 1961-2004

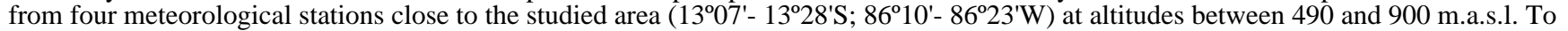
provide a more robust analysis for the baseline, we also compared the observations with Climate Research Unit TS3 dataset (CRU TS3) for the corresponding grid and period (University of East Anglia Climate Research Unit 2008). The long-term historical temperature and rainfall in general show few clear trends for many parts of Central America (Magrin et al. 2007).

For the studied area, the annual mean temperatures increased significantly, by about $0.4^{\circ} \mathrm{C} /$ decade between the $1960 \mathrm{~s}$ and the $2000 \mathrm{~s}$ (Fig A.1.1a). The average annual rainfall showed an insignificant decline, although one of the rainfall stations experienced an abrupt decline in rainfall in the late 1990s that could have influenced the trend observed (Fig A.1.1b).

Extreme weather events and associated natural hazards have been particularly connected with El Niño and La Niña cycles (NOAA, 2010). The El Niño phases were associated with warmer regional temperatures and strong rainfall anomalies (Figure A.1.1 $a$ and $b$ ), i.e., low rainfall with severe droughts $(1972,1976,1987,1990-91,1994,2004)$ and peaks in rainfall $(1966,1969,1998)$, causing floods and landslides. The La Niña phases were associated with floods, and occurred mostly in years with peak rainfall (e.g. 1968, 1970, 1998) while occasionally in years with low total annual rainfall (1962).

Fig. A.1.1a. Trends in annual mean temperature from 1961 to 2005 (the data have been standardized to facilitate comparison).

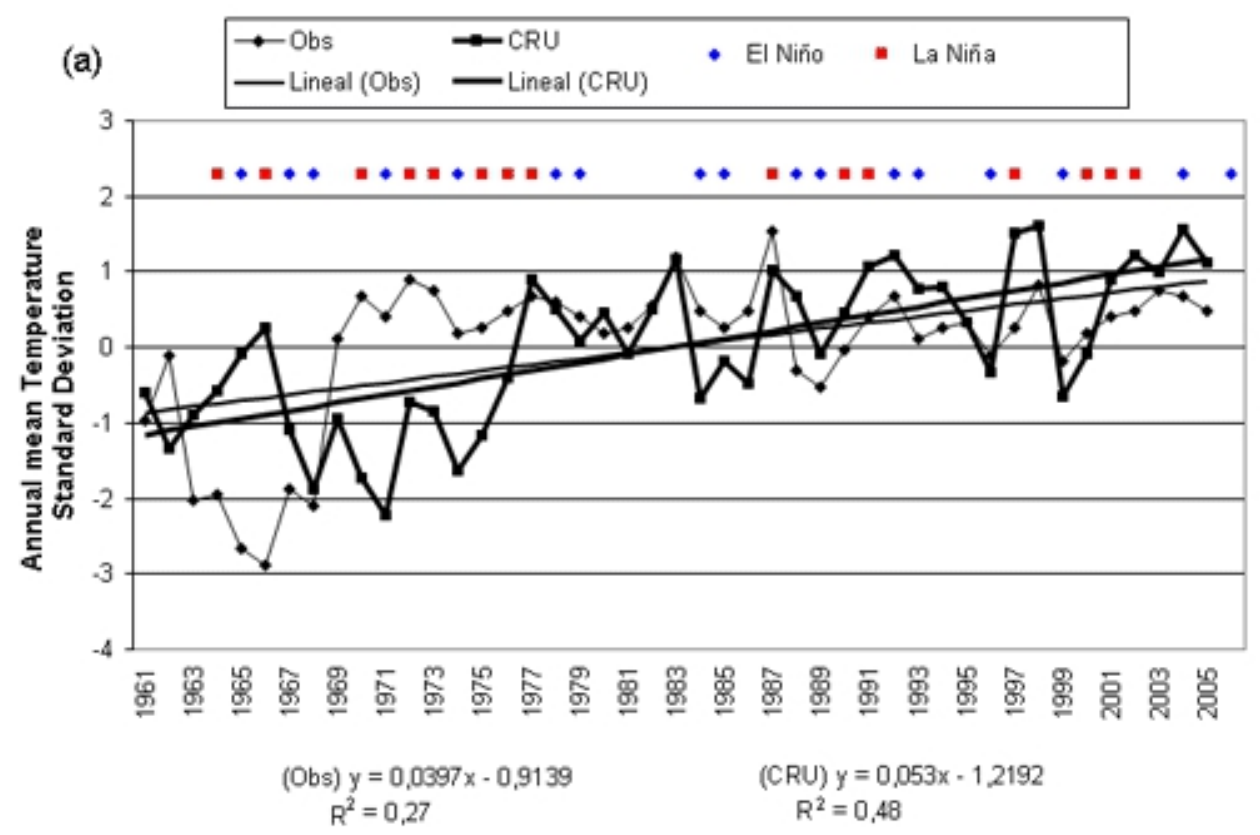


Fig. A.1.1b. Trends in annual total rainfall from 1959 to 2005 (the data have been standardized to facilitate comparison).

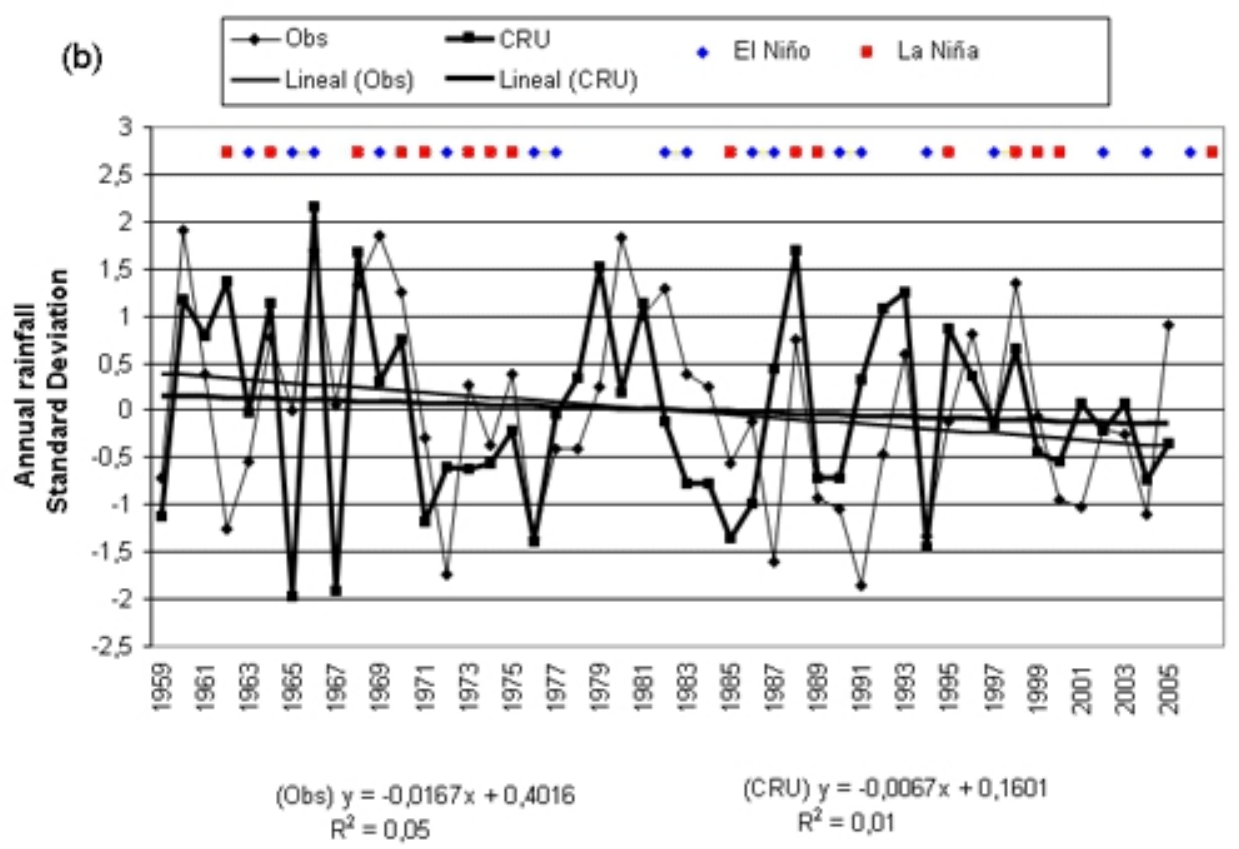

\section{Future Projections and Potential Impacts}

The future climate scenario for this study was developed from the two Special Reports on Emissions Scenarios A1B-projections for the 21st century with 1980-99 as a baseline. First, annual mean temperature and rainfall for the 2050s builds on Ruosteenoja et al. (2003). The annual changes were calculated as the mean changes for the dry and wet season, respectively. Second, seasonal changes for 2080-99 build on scenarios for Central America developed by Christensen et al. (2007). The projected differences in minimum, maximum, median, 25\%, and $75 \%$ quartiles between the baseline and 2080-99 periods were used to modify the distribution of the observed baseline. The two original sources included seven and 21 General Circulation Models, respectively.

The resulting scenarios indicate a change in annual mean temperature by $0.8^{\circ} \mathrm{C}$ for 2050 . Minimum temperatures may increase by $1.4-2.0^{\circ}$ $\mathrm{C}$ and maximum temperatures by as much as $4.6-5.5^{\circ} \mathrm{C}$. In terms of seasonal changes, the scenario indicates that winters may have more strong increases in both minimum and maximum temperatures, leading to frequent heat waves and dry spells. The change in annual mean precipitation may be more irregular and may range from $-13.5 \%$ to $+4 \%$ by 2050 . This translates to a range of about -110 to $+30 \mathrm{~mm}$ as minimum rainfall decrease by $45 \%-57 \%$, whereas maximum rainfall increases by up to $24 \%$. These scenarios further indicate that the frequency of dry seasons may increase by $15 \%-25 \%$. In contrast, the seasonal scenarios, project winters with higher intensity rainfall and stronger and/or more frequent tropical storms. Figure A.1.2 shows the ranges of change in projections of average total annual rainfall for 2090. To illustrate the likely increase in extreme events (both floods and droughts), the maximum May rainfall between 1980-99 was 565 $\mathrm{mm}$, whereas by the $2090 \mathrm{~s}$ it may reach $650 \mathrm{~mm}$. However, the median rainfall was only $80 \mathrm{~mm}$ and may decline further to $67 \mathrm{~mm}$.

Fig. A.1.2. Range of past (1980-99) and projected (by 2090s) monthly rainfall.

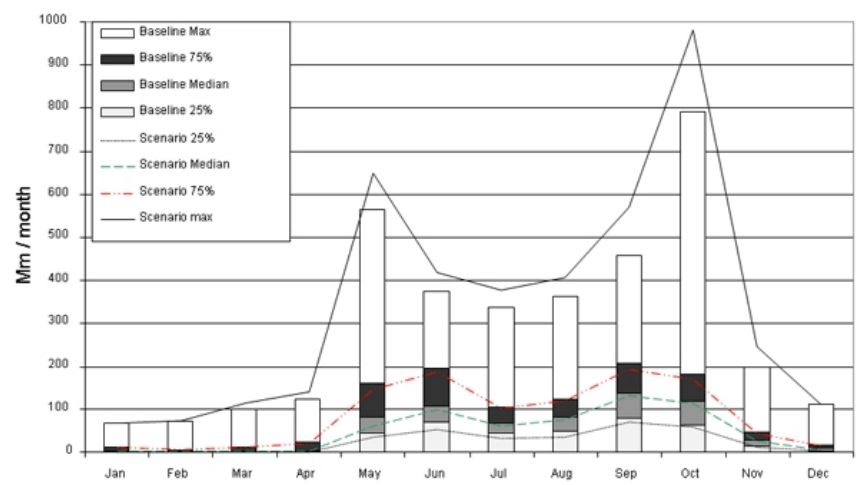


The most likely immediate impact expected in the region is a more intense and recurrent drought risk in both seasons. Moreover, flood and wind-risk damages are expected in winter under the scenario studied. Modest shifts in the seasonality can lead to remarkable ecosystem changes. Seasonally, Central American dry forests are considered severely threatened by global warming (Halpin et al. 1995,

Intergovernmental Panel on Climate Change 2007). Drought recurrence can also alter grassland/shrubland boundaries (Intergovernmental Panel on Climate Change 1998), species composition (Sala et al. 2000), reduce plant physiological functions due to heat stress (Battisti and Naylor 2008) and decrease water content in topsoil and soil erosion by wind (Magrin. et al. 2007). Grain-crop yield losses are expected to increase under extreme climatic events (Lobell et al. 2008). In particular, according to studies undertaken in Latin America's dry regions (Giménez 2006), higher minimum temperatures, combined with water limitation in the fall, may shorten the growing season. Other studies show that in medium-altitude semiarid regions of Central America, maize yields may decrease between $6 \%$ and $17 \%$ by 2055 , and other staple crops, e.g., beans, may be badly affected as a consequence of drought and other extreme climatic events (Jones and Thornton 2003). Species characterized by high reproduction rates are generally favored by temperature increases, leading to a potential rise in the distribution and occurrence of pest infestation and pathogens (Magrin et al. 2007). Consequently, increasingly fluctuating weather patterns could have a strong negative economic impact on agriculture, by increasing labor time and production costs (Intergovernmental Panel on Climate Change 1998). Similar studies in dry regions show that the expected key impacts of change in rainfall and drought recurrence and intensity on livelihoods (particularly smallholders) are: food insecurity, through diminished crop production and increased food prices (Hertel et al. 2010), declining survival rates of livestock (Richardson et al. 2007) and increasing spread of diseases, e.g., dengue/dengue hemorrhagic fever (Rosenzweig et al. 2001, Patz et al. 2005). Human migration from drought-affected areas and tenser social relations due to scarcity of land and natural resources (Barnett and Adger 2007) may also be expected in the study area. 
APPENDIX 2. Methodological details of the conceptual modeling and participatory scenario analysis.

Here, scenarios are interpreted as alternative futures that are neither predictions nor forecasts, but stylized and contrasting desirable or alarming images of how the future might unfold. Drawing on participatory research (Reed et al. in press), the scenario development in this study has some innovative merits, such as combining explorative and anticipatory methods. At the core of the framework was an iterative, two-way learning cycle between researchers and stakeholders for formulating a portfolio of environmental-management options and policy proposals for adaptation to change. The scenario analysis specifically addressed uncertainties and surprises, by incorporating alternative and potentially conflicting perspectives, values, and interests and by encouraging participation through negotiated deliberation processes. The conceptual modeling exercise and scenario analysis were developed in three key phases: (1) exploring narratives of the agropastoral system's historical and current structure and functions, (2) envisioning desirable and adverse visions for the future, and (3) backcasting to discuss how these futures could emerge and what policy options could be implemented to achieve them.

\section{Conceptual Modeling Exercise}

Once the key stakeholders'interests and relevance had been characterized (Ravera et al. 2009), their early participation was vital to ensure representative, dynamic, and durable decision making throughout the process. The historical analysis of trends and drivers of vulnerability of livelihoods in the studied area was obtained by a triangulation of participatory methods that included key informant interviews ( $\mathrm{N}=5$ ), a focus group with village elders $(\mathrm{N}=12)$, and more classical research methods such as aerial photographs and satellite-image interpretation $(1954,1971,1988,1996$, and 2008), literature review, and archive material study. Secondly, a perception analysis was carried out to explore conflicting concerns regarding environment and development issues and perceptions, and representation of changes in vulnerability. Two series of in-depth and semi-structured interviews were conducted $(\mathrm{N}=23$ and $\mathrm{N}=41$ respectively) within categories of local stakeholders (landless people, small agropastoral farmers, medium-scale semi-rural cattle raisers, traditional large-scale landowners and commercial entrepreneurs, women as single parents, and youth). They were selected through snowball sampling. Four focus groups were then involved in a collective discussion: small agropastoral male farmers $(\mathrm{N}=15)$, women $(\mathrm{N}=20)$, youth $(\mathrm{N}=12)$, and landless people $(\mathrm{N}=13)$. We also interviewed representatives of institutions interested or involved in natural resource management in the area $(\mathrm{N}=13)(\mathrm{e} . \mathrm{g}$., local authorities, government agencies, local administration, trade unions, NGOs, private enterprises) and we organized a focus group of local experts from NGOs and research institutes $(\mathrm{N}=12)$. A mix of methods was then used to code and represent local narratives, such as visual representations and grounded theory analysis applied to transcripts and combined with literature and field observations. The final decisions on how to visualize the narratives as a conceptual model were taken to two series of meetings with experts. These meetings included Nicaraguan and Spanish researchers on agroeconomy, agronomy, ecological economics, and ecology, Nicaraguan teachers, and environmental technicians. The experts also decided how to present uncertain and conflicting visions. A simplified version of the conceptual model was discussed in in-depth interviews with key informants $(\mathrm{N}=12)$ and presented back to local stakeholders during a series of extended meetings: four meetings with small farmers and landless people, two meetings with large-scale commercial traditional landowners and entrepreneurs, and a meeting with representatives of local institutions. The conceptual model was cross-validated with researchers from system analysis, ecological economy and ecology $(\mathrm{N}=5)$, and then developed in the VENSIM program.

\section{Visioning Exercise}

In a complementary exercise stakeholders, were asked to envision the connections between components and drivers to changes and future vulnerability. To account for different future visions and to discuss potential uncertainties and surprises, the focus-group participants were divided into mixed subgroups and were guided to construct a set of desirable and undesirable scenarios. To engage participants without formal education, illustrations such as collages from magazines, photographs, sketched maps of the region, etc., were used to create an image of the future and discuss associated storylines on drivers and changes in the multiple dimensions of vulnerability, based on Fraser's work (2007). A complementary series of in-depth interviews $(\mathrm{N}=23)$ was used to explore metaphors that captured stakeholders' expectations about the future. Quite independently of the details, the metaphors dramatized the inner significances of the situation and alluded to the kind of world within which stakeholders belonged. Titles and the final storylines of future scenarios were then re-elaborated by the research staff.

\section{Backcasting Exercise}

A second series of focus groups was conducted with male small farmers and landless people $(\mathrm{N}=13)$, women $(\mathrm{N}=15)$, commercial landowners and medium semi-rural ranchers $(\mathrm{N}=6)$, and local authorities and representatives of institutions $(\mathrm{N}=10)$. Here, the conceptual model inputs and scenario narratives were used as the basis for a backcasting exercise. Starting from the future scenarios, the participants were asked to go back to the present time, identifying obstacles and opportunities that might emerge on the way. For each scenario, the likeliness of factors that might influence the vulnerability was inferred. To converge conflicting interests, the likelihood and desirability of different scenarios were discussed, resulting in a compromise about a "sustainable scenario." The participants started by identifying what changes in land-use allocation, land-management practices, and socioeconomic and institutional arrangements were to be implemented at the present time, to lead to the respective future scenarios. The support of a 3D landscape model helped to ground the discussion in the current context and landscape, and to heuristically anticipate measures to avoid undesirable futures. Participants were asked to respond to a list of key policy questions, derived from the analysis of assumptions and components for the four scenarios. Then, a set of plausible pathways to achieve desirable states was created, and adaptive management strategies were discussed. Throughout the process, feedback and dissemination of information to stakeholders allowed for a dynamic participatory learning process experience, and a set of different tools were useful for overcoming language barriers and preventing misunderstandings. In the future, further research steps will use dynamic computer-based modeling to examine vulnerability indicators and empirically monitor and simulate future changes in livelihood vulnerability under each scenario and options. 
APPENDIX 3. Storylines for the scenarios.

I. "Managing in a desert" (suggested by all the stakeholders). The national and uncertain stagnant economic situation persists with falling production values and salaries. A failure in commitment from the state, lack of transparency, and fragmentation of administrative interventions continue. Institutional failures lead to natural resource mismanagement, e.g., illegal felling and unstable local governance. Landowners are reluctant to change and innovate. Land distribution and access to natural resources, such as water and firewood, are inequitable. Small and medium-scale farmers intensify production and overexploit natural resources, or sell off and move. Rural depopulation, social stratification, and local conflicts demoralize social networks. Absent on-farm job opportunities, worsening insolvency, and environmental degradation make the region dependent on external aid and food-relief programs and, hence, more sensitive to economical and environmental shocks.

II. "Community-based protectionism" (suggested by landless people, small famers and women, local authorities, and other institutions with social and environmental concerns). This is a community-based natural-resource conservation scenario with improved small-scale farming systems within a protectionist Sandinista policy framework. Investments and state-subsidized programs with credit schemes and guaranteed prices provide incentives for small farmers to explore new market opportunities. Policies on consumption, including food aid, are implemented in response to rising commodity prices. Communities, trade unions made up of small farmers, and cooperatives, are organized with NGO support, to export within Central and Latin American alliances. These schemes promote fair-trade contracts and alternative production, e.g., dairy, organic, or livestock production. Community comanagement strengthens local governance. Local communities are guaranteed access to land and natural resources by law. Large-scale commercial production doesn't receive incentives. Improved education, off-farm job opportunities, and effective international funds that support conservation programs and environmental policies contribute to reduced land pressure. Primary land use changes are a mosaic of small farmland and dry forest expansion. Diverse small-scale farming systems may provide local food.

III. "Development and conservation" (suggested by women, small farmers, medium-scale semirural cattle raisers, large-scale commercial traditional landowners). This negotiated scenario emphasizes agroenvironmental programs that encourage Payment for Ecosystem Services mechanisms, low-cost green technologies, and agroecological practices, and are enforced through international funds. State interventions promote equitable land distribution, rural investments with long-term credit, microenterprise development, and public-private partnerships between landowners and communities, food and agricultural input, and commodity price protection and other policies on production and trade. Local institutions are reinforced through decentralization and determined initiatives to reduce corruption. Agroecotourism based on traditional production and handicrafts provides local capital influx and diversifies household incomes. Off-farm economic opportunities, income redistribution, and improved labour conditions are encouraged by changes in local development pathways. As the population increases and exchanges with urban areas become more frequent, traditional values, solidarity, and local culture thereby coincide with new lifestyles.

IV. "Progress and technology" (suggested by medium-scale semirural cattle raisers, large-scale commercial traditional landowners, commercial entrepreneurs, and local institutions with development concerns). National economic growth and neoliberal policies dominate this scenario. Governmental actions and functions are constrained. Agroindustries are oriented toward dairy and meat production. Opportunistic investors and landowners take advantage of liberalized land tenure and international trade agreements. Local agropastoral systems are progressively intensified and mechanized. Small-scale and traditional farming systems vanish. Rising demand for green energy upholds land conversions toward biofuel plantations. Land concentration reinforces socioeconomic inequalities. Social programs and the creation of skilled jobs in the agroindustries have trickle-down effects on community welfare by providing new livelihood opportunities. Young people adopt modern lifestyles. 